\title{
SOME FEATURES OF THE TRANSFORMATION OF MAMMAL FAUNAS OF THE PALEARCTIC AND NEARCTIC IN THE TERMINAL CENOZOIC
}

\author{
V. N. Kalyakin \\ Zoological Museum of Moscow State University, 6 Nikitskaya, Moscow, 125009, Russia \\ E-mail:kalyakiny1939@mail.ru
}

\section{ОБ ОСОБЕННОСТЯХ ТРАНСФОРМАЦИИ ТЕРИОФАУН ПАЛЕАРКТИКИ И НЕАРКТИКИ В КОНЦЕ КАЙНОЗОЯ}

\author{
В. Н. Калякин \\ Зоологический музей Московского государственного университета, Россия, 1250о9, г. Москва, ул. Большая Никитская, 6 \\ E-mail: kalyakiny1939@mail.ru
}

\begin{abstract}
Historical changes in the terminal Cenozoic are analyzed in those mammalian species of the Palearctic and Nearctic that, interacting with soil and vegetation, made possible the pasture ecosystems that were distributed from tropical Africa to some Arctic islands. In addition to large herbivores of pasture ecosystems and carnivores feeding on those herbivores, some of the largest rodents are included in the analysis; in the Nearctic, edentates are also discussed: the specifics of their biology made them readily accessible and therefore very desired game for primitive hunters.
\end{abstract}

Key words: large terrestrial herbivores, carnivores, edentates (armadillos and terrestrial sloths), extinction, extermination, primitive hunters, terminal Pliocene, Pleistocene, Holocene.

For citation: Kalyakin V.N. Some Features of the Transformation of Mammal Faunas of the Palearctic and Nearctic in the Terminal Cenozoic. Russian Journal of Ecosystem Ecology. 2016;1(3). Available from: https://doi.org/10.21685/2500-0578-2016-3-1

Аннотация. В статье рассматриваются изменения на территориях Палеарктики и Неарктики в конце кайнозоя в составе тех видов, совокупная жизнедеятельность которых во взаимодействии с почвеннорастительным покровом определяла саму возможность существования экосистем этого типа на пространствах от тропической Африки до ряда арктических островов. Помимо фауны крупных фитофагов пастбищных экосистем и охотящихся на них хищников, в состав рассматриваемых таксонов включен ряд наиболее крупных грызунов, а для территории Неарктики - неполнозубых, биологические особенности которых делали их легкодоступной, а следовательно, и весьма желанной добычей первобытных охотников.

Ключевые слова: наземные крупные фитофаги и крупные хищники, неполнозубые (броненосцы и наземные ленивцы), вымирание и истребление, первобытные охотники, конец плиоцена, плейстоцен, голоцен.

\section{Introduction}

The choice of the territories of the Palearctic and Nearctic for this review was determined, above all, by the position of these zoogeographical regions in the extratropical zone of the Northern Hemisphere. Therefore, considerable differences in the dynamics of the faunas of these regions during the same period-from the Late Pliocene to Holocene-cannot be determined by climatic changes, which were absolutely synchronous. The timing of this period is interesting for the following two reasons: on the one hand, the possibility and necessity to analyze the compositions of large herbivore fau- nas, mainly those of pasture ecosystems, and carnivores feeding on them during the Pleistocene in the opinion of many authors, a time during which 1-19 surface glaciations took place [1] and compare them to those of the terminal prePleistocene; and on the other hand, the possibility to compare the mammal faunas of territories that primitive humans started to colonize at considerably different times. This study naturally continues the course of my earlier studies [2-5].

With this purpose, a table has been compiled using data from several main sources [6-10] and many additional ones [11-29]. 


\section{Faunistic changes}

The results given in the table summarize the faunistic changes in the Palearctic and Nearctic during the period in question and give evidence of some similarity between these changes, but at the same time of considerable differences between them. To represent them more vividly, graphs are given (Fig. 1), that take into account the changes made in the timing of the Holocene, Pleistocene, and Pliocene and confirmed by the International Commission on Stratigraphy in 2012. The graphs were based on the last line of the table, in which data on North Africa are excluded from summarized data on the Palearctic, although in most studies the mammal fauna of North Africa is usually

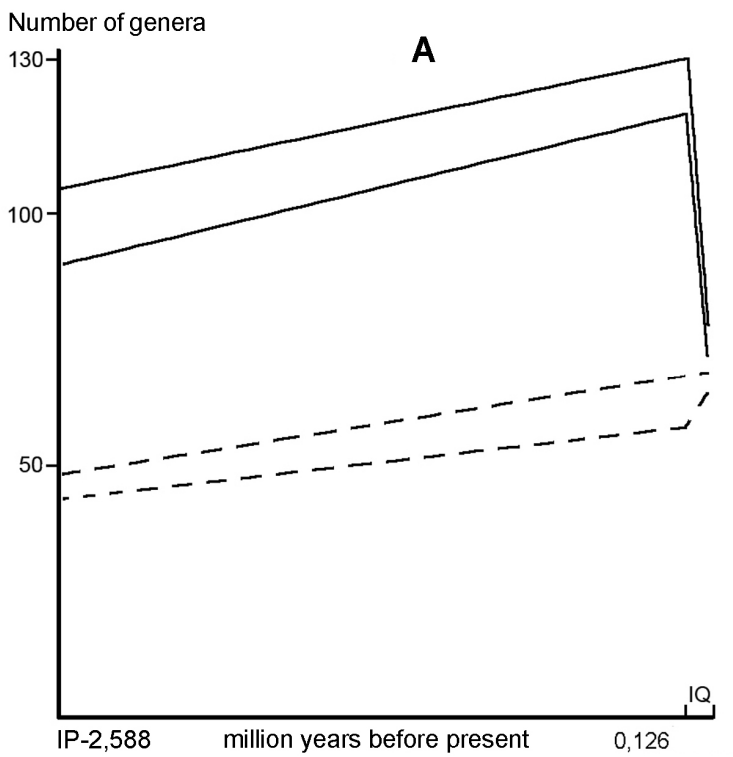

considered as part of the Palearctic mammal fauna. However, this came to be so only quite recently, as a matter of fact only in early historical times, i.e., about 2-2.5 thousand years before present. Until then the mammal fauna of North Africa was a quite natural part of purely Ethiopian mammal fauna, although peripheral and depleted. As for the changes in this fauna (Table 1), as well as the transformation of most of North Africa into the modern deserts, which began at the final stage of the Late Paleolithic and became especially evident after the advent of animal husbandry, these changes are recorded both in countless unique cave paintings $[30,31]$, first discovered before the Second World War in many areas of Central Sahara, and in corresponding paleontological finds $[32,33]$.

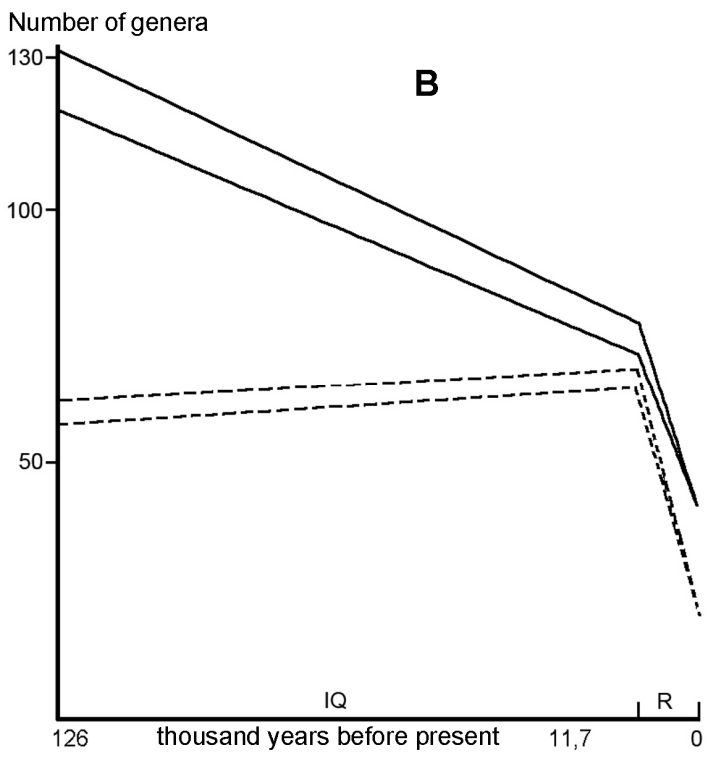

Fig. 1

Table 1

The structure of faunas (mainly at the generic level) of medium- and large-sized terrestrial herbivorous and carnivorous mammals of (over $10 \mathrm{~kg}$ ) of the Palearctic and Nearctic from the Late Pliocene to present

\begin{tabular}{|c|c|c|c|c|c|c|c|c|c|c|}
\hline \multirow{2}{*}{$\begin{array}{c}\text { Taxon (dating, } \\
\text { years before present) }\end{array}$} & \multicolumn{5}{|c|}{ Palearctic } & \multicolumn{5}{|c|}{ Nearctic } \\
\hline & IP & $\mathrm{eQ}$ & 1Q & $+\mathrm{R}$ & $\mathrm{R}$ & IP & $\mathrm{eQ}$ & 1Q & $+\mathrm{R}$ & $\mathrm{R}$ \\
\hline 1 & 2 & 3 & 4 & 5 & 6 & 7 & 8 & 9 & 10 & 11 \\
\hline Cingulata (Dasypodidae) & & & & & & & & & & \\
\hline Dasypus (CA; ?P, eQ-R - SA) & & & & & & + & + & + & & + \\
\hline $\begin{array}{l}\text { Dasypus bellus (latest 7200; } \\
\text { from Texas } 10900 \pm 190)\end{array}$ & & & & & & & & + & + & \\
\hline Cabassous (mQ-R - SA, CA) & & & & & & & & & & $\mathrm{CA}$ \\
\hline Pampatheriidae & & & & & & & & & & \\
\hline $\begin{array}{l}\text { Pampatherium, including } \\
\text { Holmesina (1P-1Q - SA - 9880) }\end{array}$ & & & & & & + & + & + & + & \\
\hline Glyptodontidae & & & & & & & & & & \\
\hline Pachyarmatherium & & & & & & & $?$ & & & \\
\hline $\begin{array}{l}\text { Glyptotherium } \\
(\mathrm{Q}-\mathrm{CA}-13970)\end{array}$ & & & & & & + & + & + & $?$ & \\
\hline Pilosa (Mylodontidae) & & & & & & & & & & \\
\hline
\end{tabular}


1

Glossotherium (1M-1Q - SA;

probably since eP; NA; Florida

9880 and $10155 \pm 270)$

Paramylodon (42500 \pm 4400$)$

Mylodon (Kentucky $10600 \pm$

250; eQ and/or mQ, 1Q - SA)

Megatheriidae

Megatherium (1P-Q - SA,

in NA from Florida to South

Carolina and Ohio)

Eremotherium $(10$ 000; ?eQ,

1Q - CA; Q - SA)

Nothrotheriops (Nevada

$8527 \pm 250$ )

Megalonichidae

Meizonyx (CA)

Megalonyx (since $1 \mathrm{M}$ - NA; 1Q -

NA to Alaska; ?eQ, $1 \mathrm{Q}-\mathrm{CA}$;

$\mathrm{Q}-\mathrm{SA}$; Georgia $9460 \pm 85$ )

Choloepus (R - SA)

Bradipodidae

Bradipus (R - SA)

Rodentia (Castoridae)

Trogontherium (eM-mQ - Eu;

$\mathrm{mM}, \mathrm{IP}-\mathrm{mQ}$ - As; mM - NA)

Eucastor (m-lM - NA;

1M-P - As)

Dipoides (since $\mathrm{lM}$ - Eu, As, NA)

Romanocastor

Zamolxifiber

Procastoroides (since eP - NA)

Castoroides (9550):

C. ohioensis (Minnesota

$10320 \pm 250)$ C. Kansasensis

(Kansas $12150 \pm 80$ ),

from New York to Nebraska

Paradipoides

Castor (since 1M)

Hystricidae

Hystrix (since ?Olig., eM;

lM-R - Af; Q, R - OI)

Erethizon

Hydrochoeridae

Neochoerus (e-1Q - SA;

$\mathrm{lQ}$ - CA; since $\mathrm{eP}-\mathrm{NA}$ )

Hydrochaeris $(\mathrm{Q}-\mathrm{NA}$; emQ,

1Q-R - SA)

Carnivora (Felidae)

Dinofelis=Therailurus $(\mathrm{IM}-\mathrm{lP}$ -

As; $1 \mathrm{M}-\mathrm{eQ}$ - Eu; eP-eQ - Af)

Lynx excluding Caracal

Puma (lP - As; ?eQ, mQ-R -

$\mathrm{SA}$; 1Q-R - CA)

Panthera (eQ-R - Af;

1Q-R - OI)

Jaguarius (since eP - NA;

mQ-R - SA; north of Mexico

extinct in basal Holocene:

Georgia $10940 \pm 210$ )

\begin{tabular}{|c|c|c|c|c|c|c|c|c|c|}
\hline 2 & 3 & 4 & 5 & 6 & 7 & 8 & 9 & 10 & 11 \\
\hline & & & & & + & + & + & + & \\
\hline & & & & & & $?$ & + & & \\
\hline & & & & & & & + & + & \\
\hline & & & & & & & & & \\
\hline & & & & & & & + & $?$ & \\
\hline & & & & & & + & + & + & \\
\hline & & & & & & + & + & + & \\
\hline & & & & & & 0 & & & \\
\hline & & & & & & & & & C \\
\hline & & & & & + & + & + & + & \\
\hline & & & & & & & & & $\mathrm{CA}$ \\
\hline
\end{tabular}




\begin{tabular}{|c|c|c|c|c|c|c|c|c|c|c|}
\hline 1 & 2 & 3 & 4 & 5 & 6 & 7 & 8 & 9 & 10 & 11 \\
\hline $\begin{array}{l}\text { Leo }(? \mathrm{eQ}, \mathrm{Q}-\mathrm{As}, \mathrm{SA} \text {; beside } \\
\text { Africa present in India; NA - } \\
10370 ; \text { Alberta } 10930 \pm 100 ; \\
\mathrm{WEu}-10670 \pm 160)\end{array}$ & & $\mathrm{m}$ & + & + & $\begin{array}{l}\text { Af, } \\
\text { SAs } \\
\text { (India) }\end{array}$ & & & + & + & \\
\hline Tigris & & + & + & & + & & & & & \\
\hline Uncia & & + & + & & + & & & & & \\
\hline Sivapanthera $(? \mathrm{eQ}-\mathrm{Af}$ & & $\mathrm{e}$ & & & & & & & & \\
\hline $\begin{array}{l}\text { Acinonyx (eP-eQ, lQ-R - Af; } \\
\text { NA: Wyoming } 10170 \pm 250)\end{array}$ & + & + & + & & + & + & $\mathrm{e}$ & + & + & \\
\hline $\begin{array}{l}\text { Machairodus (lM-eQ - Af; lM- } \\
\text { NA) }\end{array}$ & + & & & & & & & & & \\
\hline $\begin{array}{l}\text { Homotherium (to } 1 \mathrm{Q}-\mathrm{WEu} \text {, } \\
\mathrm{NAf} \text {; } \mathrm{M}-\mathrm{IP}-\mathrm{Af} ; \mathrm{eQ} / \mathrm{mQ}-\mathrm{OI} \text {; } \\
\text { in NA: Montana } 25030 \pm 510 \text { ) }\end{array}$ & + & + & + & & & + & + & + & & \\
\hline Ischyrosmilus & & & & & & + & & & & \\
\hline $\begin{array}{l}\text { Megantereon }(\mathrm{lQ}-\mathrm{NAf} \\
\mathrm{lP}-\mathrm{mQ}-\mathrm{Af} ; \mathrm{e} / \mathrm{mQ}-\mathrm{OI})\end{array}$ & + & + & & & & + & & & & \\
\hline $\begin{array}{l}\text { Smilodon (Tennessee } 9410 \pm 155 \\
\mathrm{lP}-\mathrm{lQ}-\mathrm{SA} ; \mathrm{lP}-\mathrm{CA})\end{array}$ & & & & & & + & + & + & + & \\
\hline \multicolumn{11}{|l|}{ Hyaenidae } \\
\hline Hyaena (mM, eP-R - Af) & + & + & + & & + & & & & & \\
\hline $\begin{array}{l}\text { Chasmaporthetes (since } \mathrm{lM}- \\
\mathrm{As}, \mathrm{Eu} ; ? \mathrm{lP} / ? \mathrm{eQ}-\mathrm{Af})\end{array}$ & + & $\mathrm{e}$ & & & & + & $\mathrm{e}$ & & & \\
\hline $\begin{array}{l}\text { Pachycrocuta, including } \\
\text { Parahyaena (?IM, eQ-R - Af; } \\
\text { e-mQ - OI) }\end{array}$ & + & + & & & Af & & & & & \\
\hline $\begin{array}{l}\text { Crocuta } \text { (since } 1 \mathrm{P}-\mathrm{Af} \text {; South } \\
\text { China }-11200 \pm 1000 ; \\
\mathrm{WEu}-22880 \pm 240)\end{array}$ & + & + & + & + & Af & & & & & \\
\hline \multicolumn{11}{|l|}{ Canidae } \\
\hline Borophagus & & & & & & + & & & & \\
\hline Vulpes $=$ Alopex & + & + & + & & + & + & + & + & & + \\
\hline $\begin{array}{l}\text { Canis ( since } \mathrm{lM} \text {, eQ-R - Af; } \\
\mathrm{e} / \mathrm{mQ} \text { - OI; R - CA; } 1 \mathrm{Q}-\mathrm{Med} \text {. } \\
\text { (islands Sardinia, Sicily) }\end{array}$ & + & + & + & & + & + & + & + & & + \\
\hline Cuon (e/m, 1Q-R - OI) & + & + & + & & + & & + & + & & \\
\hline \multicolumn{11}{|l|}{ Ursidae } \\
\hline $\begin{array}{l}\text { Arctodus (Kansas } 9630 \pm 60 ; \\
\text { e- } 1 \mathrm{Q}-\mathrm{SA})\end{array}$ & & & & & & & + & + & + & \\
\hline $\begin{array}{l}\text { Tremarctos (Georgia } 10940 \pm \\
210 ; \mathrm{R}-\mathrm{SA} ; ?+\mathrm{R}- \\
\text { CA(?Panama)) }\end{array}$ & & & & & & & + & + & + & \\
\hline Spelearctos (eR - Caucasus) & & + & + & + & & & & & & \\
\hline Ursus (including Thalarctos) & + & + & + & & + & + & + & + & & + \\
\hline Ailuropoda & & $\mathrm{m}$ & + & & + & & & & & \\
\hline \multicolumn{11}{|l|}{ Mustelidae } \\
\hline $\begin{array}{l}\text { Martes flavigula }(\mathrm{R}-\mathrm{S}, \mathrm{EAs}) \\
\text { genus Martes }(\text { since eM - Eu) }\end{array}$ & & & + & & + & & & & & \\
\hline Gulo & & $\mathrm{m}$ & + & & + & & $\mathrm{e}$ & + & & + \\
\hline \multicolumn{11}{|l|}{ Artiodactyla (Suidae) } \\
\hline $\begin{array}{l}\text { Chleustochoerus (1M, P - As, } \\
\text { China) }\end{array}$ & $?$ & & & & & & & & & \\
\hline $\begin{array}{l}\text { Sus (since ?mM - As; M - } \\
\text { NAf; } 1 \mathrm{M}-\mathrm{Eu} ; \mathrm{e}, \mathrm{IP} / \mathrm{eQ}-\mathrm{Med} \text {; } \\
\text { eQ-R - OI) }\end{array}$ & + & + & + & & + & & & & & \\
\hline $\begin{array}{l}\text { Hippopotamodon } \\
\text { (=Dicoryphochoerus) } \\
\text { (since } 1 \mathrm{M})\end{array}$ & + & + & & & & & & & & \\
\hline $\begin{array}{l}\text { Propotamochoerus (since mM } \\
\text { As; ?1M Af) }\end{array}$ & + & & & & & & & & & \\
\hline
\end{tabular}




\begin{tabular}{|c|c|c|c|c|c|c|c|c|c|c|}
\hline 1 & 2 & 3 & 4 & 5 & 6 & 7 & 8 & 9 & 10 & 11 \\
\hline $\begin{array}{l}\text { Potamochoerus (since } \mathrm{mM} \text { - As; } \\
\text { since } \mathrm{eP} \text { - Af; } 1 \mathrm{Q} \text { - NAf; } \\
\mathrm{R} \text { - Madagascar) }\end{array}$ & + & $\mathrm{e}, \mathrm{m}$ & $?$ & + & Af & & & & & \\
\hline Hippohyus (since $1 \mathrm{M})$ & + & $\mathrm{e}$ & & & & & & & & \\
\hline $\begin{array}{l}\text { Phacochoerus (since } \mathrm{lP}-\mathrm{Af} \\
\text { lQ - NAf) }\end{array}$ & & $\mathrm{m}$ & + & + & Af & & & & & \\
\hline Metridiochoerus (1P-mQ - Af) & & $\mathrm{m}$ & & & & & & & & \\
\hline \multicolumn{11}{|l|}{ Tayassuidae } \\
\hline $\begin{array}{l}\text { Platygonus (Ohio }-4370 \pm 150 \\
\text { lP-1Q - SA) }\end{array}$ & & & & & & + & + & + & + & \\
\hline Mylohyus (Georgia $10940 \pm 210$ ) & & & & & & + & + & + & + & \\
\hline $\begin{array}{l}\text { Tayassu (?1P, Q, R-SA; } \\
\text { lQ-R - CA) }\end{array}$ & & & & & & + & + & + & & + \\
\hline \multicolumn{11}{|l|}{ Hippopotamidae } \\
\hline $\begin{array}{l}\text { Hexaprotodon (since } \mathrm{IM}-\mathrm{Af} \\
\mathrm{lP}-1 \mathrm{Q}-\mathrm{OI})\end{array}$ & + & + & + & $?$ & Af & & & & & \\
\hline $\begin{array}{l}\text { Hippopotamus (since } \mathrm{lP}-\mathrm{Af} \text {; } \\
\mathrm{Q}-\text { Med.; +R - NAf, SWAs, } \\
\text { Madagascar) }\end{array}$ & & + & + & + & Af & & & & & \\
\hline \multicolumn{11}{|l|}{ Camelidae } \\
\hline $\begin{array}{l}\text { Hemiauchenia } \text { (since } \mathrm{mM} \text {; } \\
\text { e- } 1 \mathrm{Q}-\mathrm{SA} ; \text { Kansas } \\
13410 \pm 300)\end{array}$ & & & & & & + & + & + & $?$ & \\
\hline Pliauchenia (since 1M; 11690) & & & & & & & & + & + & \\
\hline Blancocamelus & & & & & & + & & & & \\
\hline $\begin{array}{l}\text { Camelops (California } 8550 \pm \\
100 ; 1 \mathrm{Q}-\mathrm{CA} \text { ) }\end{array}$ & & & & & & + & + & + & + & \\
\hline $\begin{array}{l}\text { Palaeolama }(9880 ; \text { Florida } \\
12350 \pm 50 ; 1 \mathrm{P}-1 \mathrm{Q}-\mathrm{SA})\end{array}$ & & & & & & & + & + & + & \\
\hline $\begin{array}{l}\text { Lama (Nevada } 12060 \pm 450 \\
\text { lP-R - SA) }\end{array}$ & & & & & & & & $?$ & + & SA \\
\hline $\begin{array}{l}\text { Camelus (since } 1 \mathrm{M} \text {; probably } \\
\text { extinct in wild state) }\end{array}$ & + & + & + & $?$ & $?$ & & & & & \\
\hline $\begin{array}{l}\text { Titanotylops (since ?P - As, } \\
\text { Eu; since eP - NA) }\end{array}$ & $?$ & & & & & + & e & & & \\
\hline \multicolumn{11}{|l|}{ Tragulidae } \\
\hline \multicolumn{11}{|l|}{$\begin{array}{l}\text { Dorcatherium (e-lM, P-As; } \\
\text { e-mM - Af; m/lM - Med., } \\
\text { Crete) }\end{array}$} \\
\hline Dorcabune (since $\mathrm{mM})$ & & $\mathrm{e}$ & & & & & & & & \\
\hline \multicolumn{11}{|l|}{ Moschidae } \\
\hline Blastomeryx (e-1M, P) & & & & & & $?$ & & & & \\
\hline Longirostrimeryx (since $\mathrm{mM})$ & & & & & & + & & & & \\
\hline Moschus (since $1 \mathrm{M})$ & $?$ & $?$ & + & & + & & & & & \\
\hline \multicolumn{11}{|l|}{ Antilocapridae } \\
\hline $\begin{array}{l}\text { Capromeryx (since P; New } \\
\text { Mexico, } 11040 \pm 500)\end{array}$ & & & & & & $?$ & + & + & + & \\
\hline Tetrameryx & & & & & & + & + & + & & \\
\hline Stockoceros (11 500) & & & & & & & $\mathrm{m}$ & + & + & \\
\hline Antilocapra & & & & & & & & + & & + \\
\hline \multicolumn{11}{|l|}{ Cervidae } \\
\hline Hydropotes (EAs) & & & & & + & & & & & \\
\hline $\begin{array}{l}\text { Platycemas }(\mathrm{P}-\mathrm{As}) \\
\text { "? deleted" }\end{array}$ & $?$ & & & & & & & & & \\
\hline Paracervulus (since $1 \mathrm{M}$ ) & + & $\mathrm{e}$ & & & & & & & & \\
\hline Muntiacus (since $1 \mathrm{M}, \mathrm{R}-\mathrm{OI}$ ) & + & + & + & & + & & & & & \\
\hline Eostyloceros $($ since $1 \mathrm{M})$ & + & $\mathrm{e}$ & & & & & & & & \\
\hline Metacervulus (since $1 \mathrm{M})$ & + & $\mathrm{e}$ & + & & & & & & & \\
\hline Elaphodus & & $\mathrm{m}$ & & & + & & & & & \\
\hline Tamanalces $(\mathrm{P}-\mathrm{EEu})$ & + & ?e & & & & & & & & \\
\hline
\end{tabular}




\begin{tabular}{|c|c|c|c|c|c|c|c|c|c|c|}
\hline 1 & 2 & 3 & 4 & 5 & 6 & 7 & 8 & 9 & 10 & 11 \\
\hline Pseudalces $(\mathrm{P}-\mathrm{WAs} ; \mathrm{P}-\mathrm{EEu})$ & $?$ & & & & & & & & & \\
\hline Torontoceros & & & & & & & & + & & \\
\hline Cervavitus (since ?m, $1 \mathrm{M})$ & + & $\mathrm{e}$ & & & & & & & & \\
\hline Pliocervus (since 1M) & $?$ & & & & & & & & & \\
\hline Arvernoceros $(\mathrm{Eu})$ & + & & & & & & & & & \\
\hline Orchonoceros (EAs) & + & & & & & & & & & \\
\hline Sinomegaceros (EAs) & + & + & + & & & & & & & \\
\hline Psekupsoceros (EEu) & & $\mathrm{e}$ & & & & & & & & \\
\hline Praemegaceros (Eu, As) & & + & & & & & & & & \\
\hline $\begin{array}{l}\text { Candiacervus (Crete, Kasos, } \\
\text { Karpathos) }\end{array}$ & & $? \mathrm{~m}$ & + & & & & & & & \\
\hline $\begin{array}{l}\text { Megaloceros (As, Eu; Middle } \\
\text { Urals } 6816 \pm 35 \text { ) }\end{array}$ & & $\mathrm{m}$ & + & + & & & & & & \\
\hline Allocaenelaphus (EEu) & & $\mathrm{m}$ & & & & & & & & \\
\hline Megaceroides (EEu; lQ - NAf) & & $\mathrm{e}$ & + & + & & & & & & \\
\hline $\begin{array}{l}\text { Nesoleipoceros (Corsica, } \\
\text { Sicily) }\end{array}$ & & & + & & & & & & & \\
\hline $\begin{array}{l}\text { Cervus (mQ-R - Malta, Sicily; } \\
\text { R - Af, OI) }\end{array}$ & + & + & + & & + & & + & + & & + \\
\hline Axis (since ?1M - As; Q-R - OI) & + & + & & & OI & & & & & \\
\hline Eucladoceros $(\mathrm{Eu})$ & + & + & & & & & & & & \\
\hline Croizetoceros $(\mathrm{Eu})$ & + & $\mathrm{e}$ & & & & & & & & \\
\hline $\begin{array}{l}\text { Elaphurus (EAs, extinct in wild } \\
\text { state) }\end{array}$ & & e & + & + & & & & & & \\
\hline Dama (?Q NAf; m/1Q - Sicily) & & + & + & & + & & & & & \\
\hline $\begin{array}{l}\text { Sangamona }(9440 ; \text { West } \\
\text { Virginia } 17060 \pm 220)\end{array}$ & & & & & & & & + & + & \\
\hline Procapreolus (since 1M) & + & $\mathrm{e}$ & & & & & & & & \\
\hline Capreolus & + & + & + & & + & & & t & & \\
\hline Cervalces (Michigan 10020 \pm 80 ) & $?$ & + & + & & & + & + & + & + & \\
\hline Alces & & $? \mathrm{~m}$ & + & & + & & & + & & + \\
\hline Bretzia (1Q/R) & & & & & & & & $?$ & $?$ & \\
\hline Odocoileus (Q - CA, SA) & & & & & & + & + & + & & + \\
\hline Blastocerus (eQ, m/lQ - SA) & & & & & & & & + & & \\
\hline $\begin{array}{l}\text { Mazama (Q, R SA; R CA; } \\
\text { R-Mexico) }\end{array}$ & & & & & & & & $?$ & & + \\
\hline $\begin{array}{l}\text { Navahoceros }(11500 \\
\text { New Mexico } 12000 \pm 400)\end{array}$ & & & & & & & & + & + & \\
\hline Rangifer & & + & + & & + & & + & + & & + \\
\hline \multicolumn{11}{|l|}{ Giraffidae } \\
\hline $\begin{array}{l}\text { Palaeotragus (since ?e, } \mathrm{mM} \text {; } \\
\text { e-lM - Af) }\end{array}$ & + & & & & & & & & & \\
\hline Sogdianotherium (As) & + & & & & & & & & & \\
\hline Macedonitherium (Eu) & + & $\mathrm{e}$ & & & & & & & & \\
\hline $\begin{array}{l}\text { Giraffa (lM,Q - As; eP-R - Af; } \\
+\mathrm{R} \text { - NAf) }\end{array}$ & + & + & + & + & Af & & & & & \\
\hline ? Honanotherium $(\mathrm{lM} / \mathrm{P}-\mathrm{As})$ & $?$ & & & & & & & & & \\
\hline Mitilanotherium $(\mathrm{EEu})$ & & $\mathrm{E}$ & & & & & & & & \\
\hline $\begin{array}{l}\text { Sivatherium (eP-lQ - Af; } \\
\mathrm{Q}-\mathrm{EEu} \text {, since eP - WAs) }\end{array}$ & + & $?$ & $?$ & + & & & & & & \\
\hline \multicolumn{11}{|l|}{ Bovidae } \\
\hline Pontoceros (EEu) & + & + & & & & & & & & \\
\hline Parabubalis (As) & & & + & + & & & & & & \\
\hline $\begin{array}{l}\text { Gazella (including Procapra; } \\
\text { since eM; eM-R - Af) }\end{array}$ & + & + & + & & + & & & & & \\
\hline Antilope (since 1M; 1P - Af) & + & + & + & & + & & & & & \\
\hline Antilospira (EAs) & + & & & & & & & & & \\
\hline Sinoreas (since eP - EAs) & & $? \mathrm{e}$ & & & & & & & & \\
\hline Parastrepsiceros (WAs) & + & & & & & & & & & \\
\hline Spirocerus (E.As; since IM CAs) & + & + & + & & & & & & & \\
\hline
\end{tabular}




\begin{tabular}{|c|c|c|c|c|c|c|c|c|c|c|}
\hline 1 & 2 & 3 & 4 & 5 & 6 & 7 & 8 & 9 & 10 & 11 \\
\hline Gazellospira (Eu, WAs) & + & $\mathrm{m}$ & & & & & & & & \\
\hline Tragospira $(\mathrm{Eu})$ & & + & & & & & & & & \\
\hline Pantholops (Q As) & & $?$ & + & & + & & & & & \\
\hline $\begin{array}{l}\text { Saiga }(\text { Eu, As; Alaska, } \\
\text { Canadian Arctic: } 12220 \pm 130)\end{array}$ & & $\mathrm{m}$ & + & & + & & $\mathrm{m}$ & + & $?$ & \\
\hline $\begin{array}{l}\text { Ourebia (?e, mQ-R - Af; } \\
\text { lQ-+R - NAf) }\end{array}$ & & & + & $?$ & Af & & & & & \\
\hline $\begin{array}{l}\text { Myotragus (Med: Balearic } \\
\text { Islands) }\end{array}$ & + & + & + & + & & & & & & \\
\hline Capraoryx $(\mathrm{EEu})$ & & $\mathrm{e}$ & & & & & & & & \\
\hline $\begin{array}{l}\text { Protoryx (since ?m, } 1 \mathrm{M}-\mathrm{As} \text {, } \\
\mathrm{EEu})\end{array}$ & + & e & & & & & & & & \\
\hline Sinocapra (China) & + & & & & & & & & & \\
\hline $\begin{array}{l}\text { Capra (since } 1 \mathrm{M}-\mathrm{As}, \mathrm{Eu} ; \mathrm{IP}, \\
\mathrm{R} \text { - NAf; } 1 \mathrm{Q} \text { - England) }\end{array}$ & & $\mathrm{m}$ & + & & + & & & & & \\
\hline Procamptoceras $(\mathrm{Eu})$ & + & $\mathrm{e}$ & & & & & & & & \\
\hline $\begin{array}{l}\text { Ovis (1Q - England, Af; R - } \\
\text { Med.) }\end{array}$ & + & + & + & & + & & $\mathrm{m}$ & + & & + \\
\hline $\begin{array}{l}\text { Ammotragus (eQ - WEu; } \\
\text { lQ-R - NAf) }\end{array}$ & & + & + & & NAf & & & & & \\
\hline Hemitragus (Eu; R - SAs) & + & + & + & & + & & & & & \\
\hline Numidocapra (NAf) & & $\mathrm{e}$ & & & & & & & & \\
\hline Rupicapra (Eu; R and WAs) & & $\mathrm{m}$ & + & & + & & & & & \\
\hline $\begin{array}{l}\text { Oreamnos harringtoni } \\
\text { (Arizona } 10870 \pm 200 \\
\text { O. americanus is extant }\end{array}$ & & & & & & & & + & + & + \\
\hline Pseudois (As) & & + & + & & + & & & & & \\
\hline Megalovis (Eu, As) & + & $\mathrm{e}$ & & & & & & & & \\
\hline Budorcas $(\mathrm{Q}, \mathrm{R}-\mathrm{As})$ & + & + & + & & + & & & & & \\
\hline $\begin{array}{l}\text { Praeovibos (As, Eu; ?e, } \\
\text { mQ - NA) }\end{array}$ & & + & & & & & + & & & \\
\hline Bootherium (Alaska $6410 \pm 120$ ) & & & & & & & $\mathrm{m}$ & + & + & \\
\hline Ovibos (Eu, As, NA) & & $\mathrm{m}$ & + & + & & & $\mathrm{m}$ & + & & + \\
\hline Symbos (Utah $7325 \pm 160)$ & & & & & & & $\mathrm{m}$ & + & + & \\
\hline Soergelia (Eu, NEAs) & & $\mathrm{m}$ & & & & & $\mathrm{m}$ & & & \\
\hline Boopsis (As) & & $\mathrm{m}$ & & & & & & & & \\
\hline $\begin{array}{l}\text { Euceratherium (California } \\
8250 \pm 330)\end{array}$ & & & & & & & $\mathrm{m}$ & + & + & \\
\hline Gallogoral $(\mathrm{Eu})$ & + & $\mathrm{e}$ & & & & & & & & \\
\hline Nesogoral (Sardinia) & & $\mathrm{e}$ & & & & & & & & \\
\hline $\begin{array}{l}\text { Naemorhedus (Q, R - As; } \\
\text { lQ - Eu) }\end{array}$ & & + & + & & + & & & & & \\
\hline $\begin{array}{l}\text { Capricornis }(\mathrm{Q}, \mathrm{R}-\mathrm{As} ; \mathrm{R}-\mathrm{OI} \\
\text { (Sumatra)) }\end{array}$ & & $?$ & $?$ & & + & & & & & \\
\hline ? Plioportax $(\mathrm{P}-\mathrm{EEu})$ & $?$ & & & & & & & & & \\
\hline $\begin{array}{l}\text { Proboselaphus (eP-1Q - China; } \\
\text { Q-OI) }\end{array}$ & + & + & + & & & & & & & \\
\hline $\begin{array}{l}\text { Boselaphus (+R to } 18 \text { in - NAf; } \\
\mathrm{R}-\mathrm{SAs})\end{array}$ & & & + & + & SAs & & & & & \\
\hline $\begin{array}{l}\text { Leptobos (lM-mQ - Eu, } \\
\text { since P - As; ?lM, ?Q - NAf) }\end{array}$ & + & + & $?$ & $?$ & & & & & & \\
\hline Parabos (since $1 \mathrm{M}-\mathrm{Eu})$ & + & $? \mathrm{e}$ & & & & & & & & \\
\hline Syncerus (1P-R - Af; 1Q - NAf) & & & + & + & Af & & & & & \\
\hline Yakopsis $(\mathrm{Eu})$ & + & & & & & & & & & \\
\hline Hemibos (As; ?1P - EAf) & $?$ & $\mathrm{e}$ & + & & & & & & & \\
\hline $\begin{array}{l}\text { Bos, including Bibos, } \\
\text { Poephagus (As, Eu; since } \\
\text { lP/eQ-+R - NAf; +R - Eu; } \\
\text { 1Q - Sicily; R - Java, Borneo; } \\
\text { Q - Alaska; Washington State } \\
610 \pm 40\end{array}$ & & e & + & & + & & $?$ & + & + & \\
\hline
\end{tabular}




\begin{tabular}{|c|c|c|c|c|c|c|c|c|c|c|}
\hline 1 & 2 & 3 & 4 & 5 & 6 & 7 & 8 & 9 & 10 & 11 \\
\hline $\begin{array}{l}\text { Bubalus (IP-R - SAs, OI; } \\
\text { lP-mQ - WEu, China) }\end{array}$ & + & $\mathrm{m}$ & + & & SAs OI & & & & & \\
\hline Agjiderebos (As) & + & & & & & & & & & \\
\hline Bison $(+\mathrm{R}-\mathrm{As}, \mathrm{R}-\mathrm{Eu})$ & & + & + & & + & & $\mathrm{m}$ & + & & + \\
\hline Platycerabos (Q; 12 950) & & & & & & & $?$ & + & $?$ & \\
\hline $\begin{array}{l}\text { Tragelaphus (1M-R - Af; } \\
\text { lQ, +R - NAf) }\end{array}$ & + & + & + & + & Af & & & & & \\
\hline $\begin{array}{l}\text { Taurotragus (lP-R - Af; } 1 \mathrm{Q}, \\
+\mathrm{R} \text { - NAf) }\end{array}$ & + & + & + & + & Af & & & & & \\
\hline $\begin{array}{l}\text { Redunca (?1M, IP-R - Af; ?1M- } \\
\text { As, N-W Iran; 1Q, +R - NAf) }\end{array}$ & & & + & + & Af & & & & & \\
\hline $\begin{array}{l}\text { Kobus (eP-R - Af; 1Q, +R - } \\
\text { NAf) }\end{array}$ & & & + & + & Af & & & & & \\
\hline $\begin{array}{l}\text { Hippotragus (eQ - As; } 1 \mathrm{P}-\mathrm{R}- \\
\text { Af;?+R - NAf) }\end{array}$ & + & $\mathrm{e}$ & + & + & Af & & & & & \\
\hline $\operatorname{Addax}(\mathrm{lQ}, ?+\mathrm{R}-\mathrm{NAf} ; \mathrm{R}-\mathrm{Af})$ & & & + & + & Af & & & & & \\
\hline $\begin{array}{l}\text { Oryx (lP-R - Af; +R - NAf, } \\
\text { WAs) }\end{array}$ & $?$ & $\mathrm{e}$ & + & + & Af & & & & & \\
\hline $\begin{array}{l}\text { Alcelaphus }(\mathrm{lQ}-+\mathrm{R}-\mathrm{SWAs} \\
\text { NAf; since } \mathrm{lP}-\mathrm{Af})\end{array}$ & & & + & + & Af & & & & & \\
\hline $\begin{array}{l}\text { Damalops (Middle, SAs; ?1P - } \\
\text { Af) }\end{array}$ & + & $\mathrm{e}$ & & & & & & & & \\
\hline $\begin{array}{l}\text { Connochaetes (1P-R - Af; } \\
\text { lQ, ?+R - NAf) }\end{array}$ & & & + & + & Af & & & & & \\
\hline $\begin{array}{l}\text { Damaliscus (lP-R - Af; 1Q, } \\
\text { ?+R - NAf) }\end{array}$ & & + & + & & Af & & & & & \\
\hline \multicolumn{11}{|l|}{ Perissodactyla (Equidae) } \\
\hline Nannipus (since mM) & & & & & & + & & & & \\
\hline $\begin{array}{l}\text { Hipparion (since } \mathrm{mM} \text {; } 1 \mathrm{M}-\mathrm{mQ}- \\
\text { Af; } 1 \mathrm{M} \text { - Crete; } 1 \mathrm{M}-\mathrm{CA})\end{array}$ & + & $\mathrm{E}$ & & & & & & & & \\
\hline Proboscidipparion (As) & + & $\mathrm{E}$ & & & & & & & & \\
\hline $\begin{array}{l}\text { Cormohipparion (since mM } \\
\text { NA; since } 1 \mathrm{M} \mathrm{Eu,} \mathrm{As,} \mathrm{CA)}\end{array}$ & & & & & & + & & & & \\
\hline $\begin{array}{l}\text { Hippidion ( since } 1 \mathrm{M}, \mathrm{IP} / \mathrm{eQ}- \\
\mathrm{NA} \text {; since } \mathrm{PP}-\mathrm{SA} \text {, where } \\
\text { it became extinct about } \\
8 \text { thousand years } \\
\text { before present) }\end{array}$ & & & & & & $?$ & $? \mathrm{e}$ & & & \\
\hline $\begin{array}{l}\text { Onohippidium (eP - NA; } \\
\text { since } \mathrm{IP}-\mathrm{SA})\end{array}$ & & & & & & $?$ & $?$ & $?$ & & \\
\hline $\begin{array}{l}\text { Equus, including Amerhippus, } \\
\text { Asinus, Hemionus, Onager } \\
\text { (since eP - NA, where it } \\
\text { survives or almost survives } \\
\text { to European colonization; } \\
\text { Washington } 595 \pm 50, \text { Ontario } \\
895 \pm 110 \text {; since } 1 \mathrm{P}-\mathrm{As}, \text { Eu, } \\
\text { Af; m-1Q - SA, } 1 \mathrm{Q}-\mathrm{CA} \text { ); } \\
\text { *subgenus Equus in probably } \\
\text { extinct in Eurasia in wild state }\end{array}$ & + & + & + & $+*$ & $+;$ Af & + & + & + & + & \\
\hline \multicolumn{11}{|l|}{ Rhinocerotidae } \\
\hline Itanzatherium (As) & $?$ & $?$ & & & & & & & & \\
\hline $\begin{array}{l}\text { Aceratherium (1Olig-M - As, } \\
\text { Eu, ?eP, ?Q - As; e-lM - Af; } \\
\text { ?mM - Crete) }\end{array}$ & & $?$ & $?$ & & & & & & & \\
\hline Elasmotherium (As, Eu) & + & + & + & & & & & & & \\
\hline $\begin{array}{l}\text { Dicerorhinus (1. Olig. - lQ Eu; } \\
\text { eM-1Q - Af; ?+R - NAf; } \\
\text { mM-R - SEAs; R - OI) }\end{array}$ & + & + & + & $?$ & SAs OI & & & & & \\
\hline $\begin{array}{l}\text { Coelodonta }(\text { since } \mathrm{IP}-\mathrm{As} \\
\text { since } \mathrm{mQ}-\mathrm{Eu} ;+\mathrm{R}-\mathrm{As}, ?-\mathrm{Eu} ; \\
\text { Middle Urals } 9510 \pm 260)\end{array}$ & + & + & + & + & & & & & & \\
\hline
\end{tabular}




\begin{tabular}{|c|c|c|c|c|c|c|c|c|c|c|}
\hline 1 & 2 & 3 & 4 & 5 & 6 & 7 & 8 & 9 & 10 & 11 \\
\hline $\begin{array}{l}\text { Rhinoceros (lM-1Q; ?1 M, } \\
\text { Q - Af; eP-R-SAs; R - OI) }\end{array}$ & + & $\mathrm{e}$ & + & & SAs OI & & & & & \\
\hline $\begin{array}{l}\text { Ceratotherium (since } 1 \mathrm{M}-\mathrm{Af}, \\
\text { Eu, WAs; ?+R - NAf, WAs; } \\
\text { ?1M - Sicily) }\end{array}$ & & & + & ? & Af & & & & & \\
\hline $\begin{array}{l}\text { Diceros (mM-Q; eP-R - Af; } \\
\text { 1Q, ?+R - NAf) }\end{array}$ & + & + & + & + & Af & & & & & \\
\hline \multicolumn{11}{|l|}{ Tapiridae } \\
\hline $\begin{array}{l}\text { Tapirus (Florida } 10155 \pm 270 \\
1 \mathrm{M}-\mathrm{Q} \text { Eu; } 1 \mathrm{M}-\mathrm{R}-\mathrm{SAs} ; ? \mathrm{e} \\
\mathrm{lP}-\mathrm{R}-\mathrm{SA} ; \mathrm{Q}, \mathrm{R}-\mathrm{CA} \text { ) }\end{array}$ & + & $?$ & ? & & OI & + & + & + & + & $\mathrm{CA}$ \\
\hline $\begin{array}{l}\text { ?Megatapirus (SAs, ?South } \\
\text { China) }\end{array}$ & & $\mathrm{m}$ & + & + & & & & & & \\
\hline \multicolumn{11}{|l|}{ Uranotheria (Mammutidae) } \\
\hline $\begin{array}{l}\text { Mammut (New Jersey } 5220 \pm \\
120 ; 1 \mathrm{M}-\mathrm{P}-\mathrm{As} \text {; to eQ - Eu; to } \\
\text { ?eQ - Af; since eP - NA; Q - } \\
\mathrm{CA})\end{array}$ & + & $\mathrm{e}$ & & & & + & + & + & + & \\
\hline \multicolumn{11}{|l|}{ Gomphotheriidae } \\
\hline Sinomastodon (E. As) & + & $\mathrm{m}$ & & & & & & & & \\
\hline $\begin{array}{l}\text { Rhynchotherium } \\
\text { (since mM; 1M CA) }\end{array}$ & & & & & & $?$ & & & & \\
\hline Stegomastodon (since eP) & & & & & & + & $\mathrm{m}$ & & & \\
\hline $\begin{array}{l}\text { Haplomastodon } \\
\text { (Q CA; P/eQ-1Q SA) }\end{array}$ & & & & & & $?$ & ? & ? & & \\
\hline $\begin{array}{l}\text { ?Notiomastodon (SA; not } \\
\text { recorded in NA so far) }\end{array}$ & & & & & & ? & e SA & & & \\
\hline $\begin{array}{l}\text { Cuvieronius (IM-1Q - NA; 1Q - } \\
\text { CA; ?1P,Q - SA; SA - 11380) }\end{array}$ & & & & & & + & + & + & ? & \\
\hline \multicolumn{11}{|l|}{ Elephantidae } \\
\hline $\begin{array}{l}\text { Tetralophodon (since mM; } \\
\text { m-lM, ?eP - Af; eP-mQ - NA) }\end{array}$ & & $\mathrm{e}$ & & & & + & $\mathrm{m}$ & & & \\
\hline $\begin{array}{l}\text { Anancus (since } 1 \mathrm{M} ; \mathrm{m}-\mathrm{lM}- \\
\mathrm{NA} ; 1 \mathrm{M}-\mathrm{eQ} \text { - Af) }\end{array}$ & + & $\mathrm{e}$ & & & & & & & & \\
\hline $\begin{array}{l}\text { Stegolophodon (since eM-As, } \\
\text { Japan; ?P - Eu) }\end{array}$ & + & ?e & & & & & & & & \\
\hline $\begin{array}{l}\text { Stegodon (since } \mathrm{lM}-\mathrm{As}, \\
\text { Japan, Taiwan, northeastern } \\
\text { China; } 1 \mathrm{P}, \mathrm{Q}-\mathrm{OI})\end{array}$ & + & + & + & + & & & & & & \\
\hline $\begin{array}{l}\text { Mammuthus, Archidiscodon } \\
\text { (eP-mQ - Af; } 1 \mathrm{P}-\mathrm{CA} ; \\
\text { Wrangel Island } 3685 \pm 60 ; \\
\text { Zhaoyuan (China) - } 3584 \pm 104 ; \\
\text { Oklahoma (United States) - } \\
2050 \pm 580 ; \text { Vologda Oblast } \\
9760 \pm 40 \text { ) }\end{array}$ & + & + & + & + & & & $\mathrm{e}$ & + & + & \\
\hline $\begin{array}{l}\text { Elephas, Palaeoloxodon } \\
\text { (As, Japan, Taiwan, Tilos, } \\
\text { Rhodes in Holocene; } \\
\text { to Holocene? - NAf; R-SAs) }\end{array}$ & + & + & + & + & SAs OI & & & & & \\
\hline Total number of genera & $90-105$ & $120-131$ & $84-90$ & $33-39$ & $42-43$ & $43-48$ & $58-63$ & $64-68$ & $32-40$ & 20 \\
\hline $\begin{array}{l}\text { Total number of genera, } \\
\text { excluding North Africa } \\
\text { from the Palearctic }\end{array}$ & 90-105 & $120-131$ & $72-78$ & $19-23$ & $41-42$ & $43-48$ & $58-63$ & $64-68$ & $32-40$ & 20 \\
\hline
\end{tabular}

Note: Olig. - Oligocene, M - Miocene, P - Pliocene, Q - Pleistocene (for every period: 1 - Late, e - Early, $\mathrm{m}$ Middle), "?" in eQ column - early or middle Q, but in other columns "?" indicates doubts of source author about precision of following dating, but not further dating, if they are given; + (in eQ column) - both Early and Middle; +R - extinct in Holocene or at boundary between Late Pleistocene and Holocene; R - recent; As - Asia, Eu - Europe, Af Africa (N - northern, S - southern, W - western, E - eastern, C - central), OI - Ost-India. NA - North America; CA Central America; SA - South America, Med - Mediterranean islands. 
So, what follows from the given graphs, in both of which the upper curve represents the Palearctic fauna and the lower curve represents the Nearctic fauna?

First, let us note the similarities. Both in the Palearctic and in the Nearctic, the faunas of the studied groups proved more depleted in the Late Pliocene than in the Early and Middle Pleistocene, but the recent faunas are even more depleted. However, neither fact can be linked to changes of the climate.

Second, let us discuss the differences. The greater richness of the Palearctic fauna compared to the Nearctic fauna is quite logical in the light of the much larger area of the Palearctic and its broader connections in both space and time with the faunas of the adjacent zoogeographical regions (Ethiopian and Indomalaysia). The direct contact of the Nearctic with the adjacent Neotropical region was most probably re-established only in the Late Pliocene, i.e. about 3 million years before present or somewhat earlier, following a period of isolation that lasted during the entire preceding part of the Cenozoic or even since the Late Cretaceous, over 60 million years before present [34, 35]. Therefore, this difference is quite natural. The differences between the Late Pleistocene histories of the Palearctic and Neotropic mammal faunas are much more considerable. Having reached a maximum of generic diversity in the Late and Middle Pleistocene (121-132 genera), the Palearctic fauna then dramatically becomes depleted: the number of genera decreases to 73-79 in the Late Pleistocene. During the same period, the corresponding fauna of the Nearctic grows from 59-64 to 65-69 genera. However, during the last 55 thousand years, the depletion of the Nearctic fauna was more intense than that of the Palearctic. Furthermore, during the very last few millennia of the Pleistocene, 6-12 taxa, including one species, became extinct in the Nearctic, and already in the Holocene the fauna of the Nearctic included only $32-40$ genera. A total of 32-40 genera of 65-69 became extinct in the Nearctic, and the ranges of eight genera are confined in the north within the boundaries of Central America. It should be noted that radiocarbon dates of the latest known records are available for 42 genera and two species that disappeared from the Nearctic fauna over the last 55 thousand years (i.e., since the earliest occurrence of humans in North America according to the available data). It is very revealing that the latest records are at most 10 thousand years old in 23 of these genera, at most 11 thousand years old in six of them, less than 12 thousand years old in four, and less than 14 thousand years old in two; i.e., at least 34 taxa became extinct during the Holocene (32 genera and 2 species). The latest records of two more gen- era are dated to earlier times: 42500 years before present (Paramilodon) and 25030 years before present (Homotherium). The latest date of the latest known record among Nearctic carnivores is that of Smilodon (9410 years before present), whereas in the Palearctic only Homotherium survived until the Late Pleistocene - a genus once distributed from Alaska to Java. It would seem that the easily accessible armadillos and terrestrial sloths could have become extinct, precisely as a result of hunting by primitive humans, earlier than the other mammals. Indeed, almost all of them became extinct by the terminal Pleistocene or in the very basal Holocene. However, one representative of each of these two groups managed to survive longer in the Nearctic: the latest record of a $2 \mathrm{~m}$ long terrestrial sloth Nothrotheriops from Nevada is dated to 8527 years before present, and the latest record of the armadillo Dasypus bellus from Texas, a species twice as large as the recent Dasypus novemcinctus, is dated to as late as 7200 years before present. It should be noted that while terrestrial sloths and giant armadillos became completely extinct both in the $\mathrm{Ne}$ arctic and in the Neotropic, a total of 21 species of smaller armadillos, which represent eight or nine genera, remain extant in South and Central America and some coastal islands of the Caribbean Sea. The above-mentioned Dasypus novemcinctus has colonized also the southern areas of the Nearctic, which happened most probably rather recently; in any case, even in the 20th century its range is known to have expanded northward. Only one of the 20 or 21 extant armadillo species, Priodontes giganteus, which lives in central and eastern areas of Brazil, reaches a rather great size: a length of 1 $\mathrm{m}$ and a weight of $55 \mathrm{~kg}$, whereas glyptodonts and Glyptotherium were 2-2.5 m long and could weigh up to $1 \mathrm{t}$ or more. Woolly mammoths, the largest terrestrial herbivores, disappeared in the Nearctic much later than in the Palearctic. The latest dates of mammoth fossils are as follows: in Oklahoma 2050 years before present, in Michigan 3310 years before present, in Arizona 3320 years before present, in Alaska 3500 years before present, in Calgary, southwestern Canada, 4080 years before present, in Idaho 4300 years before present, in Ontario 4370 years before present. These dates give evidence that this species was widespread even relatively recently. In absolutely most of the Palearctic, the woolly mammoth disappeared much earlier; the latest dates of fossil records during the early Holocene are known from Estonia, Vologda Oblast, Taimyr Peninsula, and New Siberian Islands $[36,37]$. The woolly mammoth remained extant much longer on Wrangel Island (3685 years before present), on which the latest mammoths were nearly half as large as the original form (inevitable consequence of long life on rather small arc- 
tic islands in many larger animals) and in northwestern China (3584 years before present). A dwarf form of the Asian elephant survived on some islands of the Eastern Mediterranean until the times of the pharaohs, $1445 \mathrm{BC}$ [38]; it is assigned by some authors to the forest elephant genus Palaeoloxodon. Stegodon survived in Yunnan, China, until the Neolithic, up to 4100 years before present [39]. The American mastodon Maтmut americanum survived in the Nearctic at least until the Middle Holocene (the latest record, from New Jersey, is dated to 5220 years before present), although in the Palearctic this genus disappeared as early as the Early Pleistocene. Wild horses and yaks lived in the Nearctic much longer than was believed only recently. The latest records of the horse (595 years before present in the state of Washington and 895 years before present in Ontario) show that it survived almost until the European colonization, or even later, which cannot be excluded. An even later record, $410 \pm 100$ years before present from Michigan, without knowledge of any details, cannot be reliably assigned to the wild horse, rather than to the horse introduced by the colonists. The latest record of the yak, $610 \pm 40$ years before present in the state of Washington, gives evidence that this species managed to disperse over the Rocky Mountains far south. It is quite obvious that the latest radiocarbon dates given in the table are actually not the latest dates and only roughly give some evidence of the timing of extinction for different taxa, which in reality in the vast majority of cases became extinct only somewhat later. Therefore, all genera recorded during the last millennia of the Pleistocene are provided with a question mark in column $+R$ (i.e., those that became extinct in the Holocene). The above-given examples raise several questions. The first and foremost is how to explain such a strong difference in the timing of rather dramatic depletion between the Palearctic and Nearctic faunas discussed here. In the Palearctic extinction takes place in two stages: during the first, long stage, from the Early-Middle to Late Pleistocene, the fauna becomes depleted to nearly half of its initial size; during the second stage, from the Late Pleistocene to present, the total depletion is only one-fifth to one-sixth of the earlier depletion, but the intensity of extinction is considerably higher, possibly even by a factor of magnitude, considering the much greater duration of the first stage (by a factor of 20-30 or even more). By contrast, in the Nearctic, during the first stage of similar length, the fauna does not become depleted at all: it even becomes somewhat richer, but during the second stage it becomes depleted mainly during a period only one or two millennia longer than the entire Holocene; i.e., the "effectiveness" of extinction in the Nearctic during the last 13 or 14 millen- nia is similar to that "achieved" in the Palearctic during many tens (or even hundreds) of millennia. As a result, the fauna of the taxa in question in the Palearctic currently makes up $31.1-34.7 \%$ of the maximum size of this fauna of the Early-Middle Pleistocene (i.e., also during the entire period of about 3 million years treated in this study), and the corresponding fauna in the Nearctic is $30.4-32.3 \%$ its maximum size of the Late Pleistocene, terminal Cenozoic. It has already been mentioned above that this sharply pronounced difference can by no means be linked to climate: it is quite obvious that the Palearctic and Nearctic are situated in the same climate zones, and the extinctions themselves, although much more rapid in the Nearctic than in the Palearctic, are nevertheless stretched over 13-14 millennia. Therefore, the most likely cause of these differences, as well as the most likely cause of the extinctions themselves, is human activity. The dispersal of Homo erectus, the direct ancestor of modern humans, from Africa to the Palearctic and Southeast Asia, took place over 1 million years before present and was not at all the only such event [40]. The age of the Peking men, which had mongoloid features, is estimated to at least 370 thousand years [41]. It was most probably by the later Peking men that the wolf was first domesticated [3], thus becoming a companion also of modern humans that dispersed from Africa [42] on their way from South-Southeast Asia to Australia. At least 200 thousand years before present, the Palearctic was inhabited by Neanderthal men, their genes (up to 4,5\%) are present in the genotypes of modern humans, that replaced one of its ancestors, the Neanderthal man, during the period from 45 to 27 thousand years before present [43]. Many data give evidence that during the late Le Moustier Neanderthal men already successfully hunted woolly mammoths [44, 45], and most probably had an indispensable helper in the domesticated wolf, as directly confirmed by the data obtained by Ovodov et al. [46] in the Altai. Thus, in the Palearctic humans in possession of fire affected the environment for hundreds of millennia. It is very unlikely that the earliest humans penetrated into North America earlier than 55 thousand years ago. In the opinion of most experts, successful colonization of the New World by modern humans via Alaska and their subsequent dispersal south took place about 15 thousand years before present or somewhat later [43], which is indirectly confirmed also by rather numerous data given in the table and results of radiocarbon dating from sites of primitive humans known in North America. Subsequently the growth of the number of later radiocarbon dates accelerates: 18 from 55 to 45 thousand years before present, 65 from 25 to 15 thousand years before present, and then 14 during the 14th millennium, 
16 during the 13th millennium, 56 during the 12th millennium, 121 during the 11th millennium, 217 during the 10th millennium, then growing exponentially [10]. Thus, professional woolly mammoth hunters that colonized America accompanied by the wolf (dog) began to disperse rapidly and grow in numbers more and more, beginning with 13-12 thousand years before present. It is very revealing that in the first one-third of the Holocene the number of recorded stone spearheads and darts used for hunting large carnivores that lived in the Great Plains, where they were especially abundant, is greater by several orders of magnitude than the number of the same tools recorded in other areas of the United States [47]. As a result, almost all main game of the primitive hunters (whose mode of life remained unchanged in northern parts of the continent for some time even after the start of the European colonization of America) became totally extinct already in the Holocene [48]. By that time, only the bison, pronghorn, and reindeer remained extant of the truly abundant larger herbivore species. The balance required by that essentially closed system was established between the abundance of those herbivores and the population size of the primitive hunters that existed mostly on this game. In the Palearctic (and to a smaller extent in the Neotropic), the Mesolithic crisis, largely caused by the dramatic decrease in abundance of the principal game species on which the primitive hunters mainly lived, eventually led to the Neolithic revolution, the advent of crop farming and animal husbandry, initially narrowly regional, but rather soon spreading wider and wider [49]. It was this revolution that postponed the moment of final extinction or the critically low abundance for several most important game species. At the same time, in the Palearctic degradation of initial pasture ecosystems started much earlier and went much farther, very strongly increasing the risk of extinction in some species or resulting in dramatically shrinking ranges in others. These ecosystems are now completely replaced with continuous forests over huge areas with the most humid climate. Most lately, during less than three centuries, the forests have been barbarously cut in places and affected by other anthropogenic factors. It is typical that over the last few millennia not a single large herbivore of the typical edificator assemblage of pasture ecosystems has preserved in the Palearctic a range close to initial and similar to the current range of the American bison, which stretches from Alaska to the Gulf of Mexico and northeastern Mexico. The range of the North American arboreal porcupine Erethizon dorsatum, the only species of the genus Erethizon (Erethizontidae), is even more stunning. This species evolved in South America since the Oligocene and penetrated into North America only in the Late Pliocene, when the "splendid isolation" [34] of the Neotropic and Nearctic regions ended. As for the remaining 12 species, one of them is distributed only in Central America (from Central Mexico to Panama), the range of another one encompasses the tropical forests of South and Central America, one lived on the Greater Antilles but became extinct during historical times, and all others are distributed within the limits of South America [28]. In this connection, the generic composition of the fauna of Alas$\mathrm{ka}$, the northernmost continental area of North America, during the coldest time of the Pleistocene (17 to 26 years ago) and comparison of this composition with the current composition of this fauna are of special interest. Such a comparison became possible following the review of 2654 radiocarbon dates of terrestrial mammal fossils of North America published by Levi et al. [8-10]. During the coldest time of the Late Pleistocene, in addition to recent genera that currently live in Alaska, the fauna of this peninsula included the following genera and species, currently either extinct (in North America or everywhere) or confined to more southern ranges: Megalonyx, Arctodus, Camelops, Saiga, Bootherium, Equus, Mammut, and Mammuthus comprise the former group, and Taxidea taxus, Puma concolor, and Cervus elaphus comprise the latter group. Of the last three species, the North American badger Taxidea taxus displays the most considerable shrinking of range. But the ranges of two related species of steppe polecats, Mustela eversmanni, distributed in Eurasia, and M. nigripes, distributed in North America, have shrunk even more dramatically; the latter species is a subspecies of the former (Fig. 2, 3; [13]). The records of these species have earlier dates in Alaska: $33550 \pm 350$ years ago for M. eversmanni, and $30370 \pm 560$ years ago for $M$. nigripes. The shrinking of the range of the Eurasian steppe polecat to date is quite comparable in scale to the retreat of Saiga and the horse (subgenus Equus) to Eurasia and subsequent shrinking of their ranges, although it is possible that the horse has already become extinct in the wild in Eurasia. It is also very revealing that the ranges of such mammals as the tapir and jaguar, currently distributed in the north within the boundaries of Central America, stretched much farther northward during the coldest period. The tapir was distributed to the modern Pennsylvania, and the jaguar was distributed to Tennessee, where their ranges overlapped with the range of reindeer. At the same time, the artic lemming, currently indigenous to the Artic and Subarctic, was distributed in the south to Iowa. 


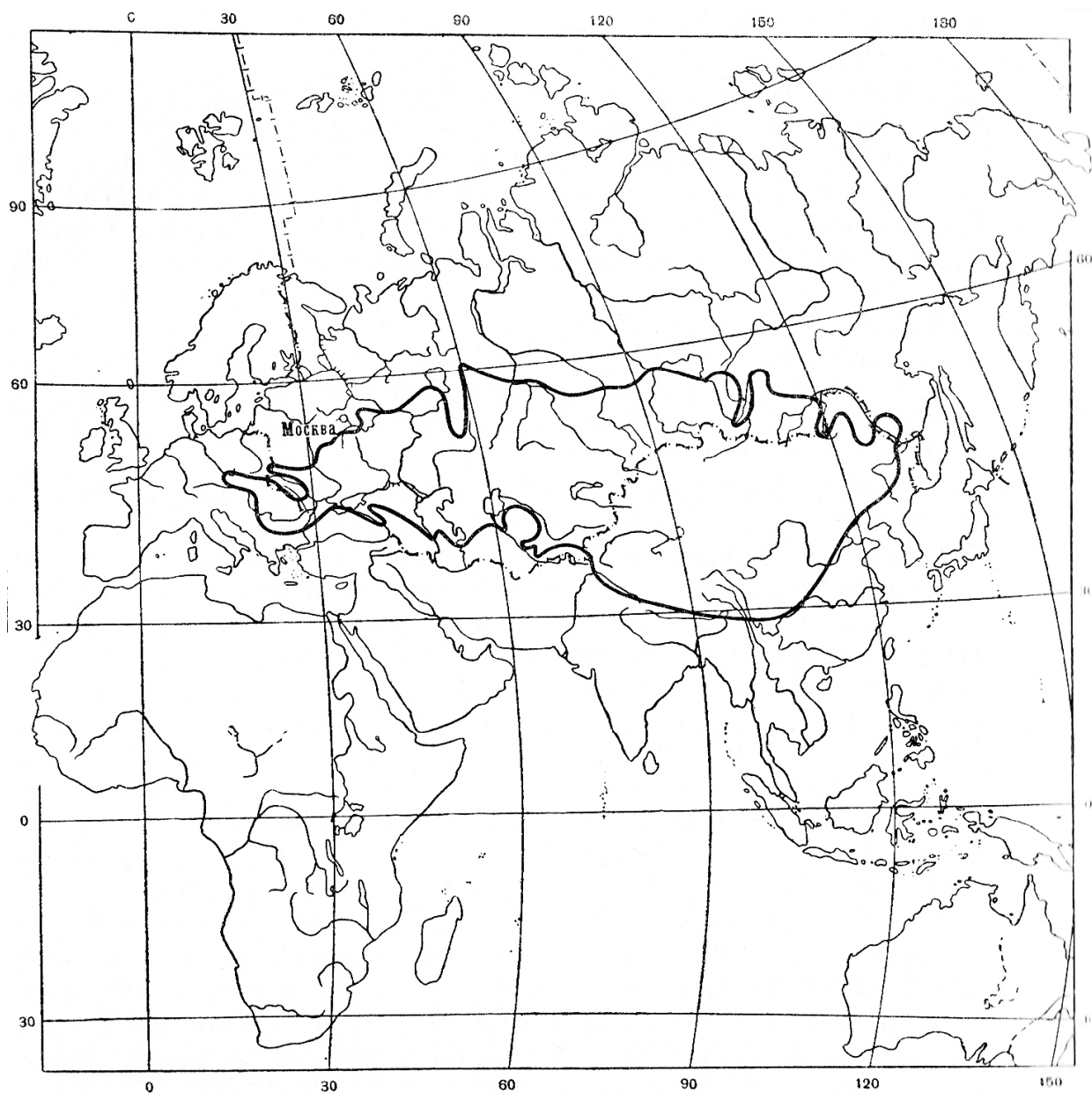

Fig. 2

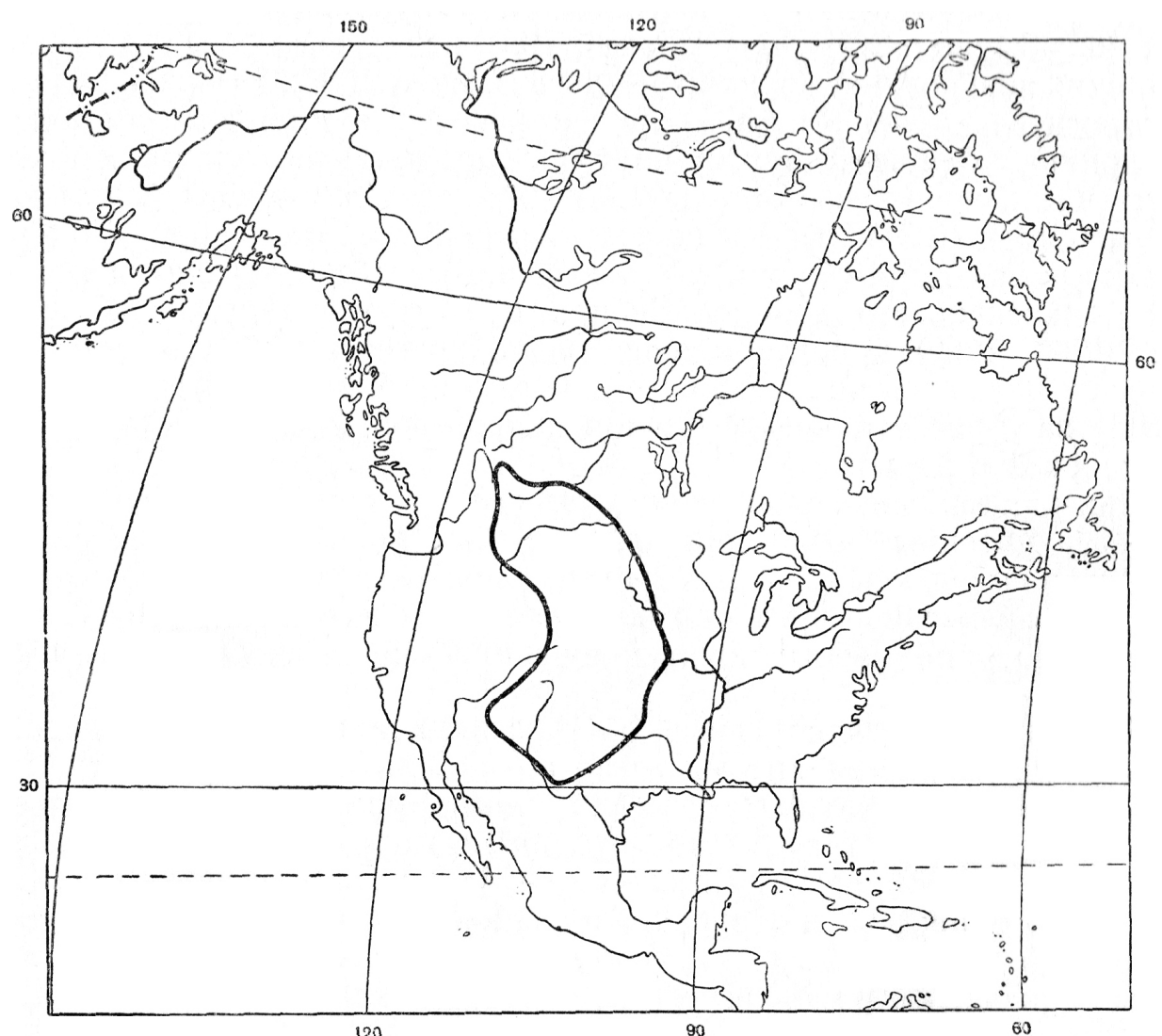

Fig. 3 
Rather many other similar examples on both the Nearctic and Eurasia can be given. Since the Late Pleistocene fauna of the New Siberian Islands has already been discussed in my previous contribution, let us limit the discussion to the examples of the British Isles and Scandinavia, which, according to very many authors, during the coldest period were covered with glaciers that crawled further south over the plains of Europe. The following radiocarbon dates are available for woolly mammoth fossils from Finland: 13 133, 13 134, 13 180, 15 761, $16120,16121,16122,24$ 450, and 43000 years before present; $15500 \pm 65,22420 \pm 315,23340 \pm$ $\pm 350,24450 \pm 390,25200 \pm 500,28740 \pm 670$, $31970 \pm 950$, and $34300 \pm 2000 / 1450$ years before present [9]. From the coldest period of the Pleistocene in the British Isles, dates are available for the wolf, red fox, brown bear, wolverine, moose, red deer, giant deer, reindeer, bison, muskox, woolly rhinoceros, woolly mammoth, and revealingly - cave hyena Crocuta crocuta spelaea (not reaching far northward anywhere in Eurasia during the Pleistocene), as well as the mole Talpa, which, like the other above-listed species, cannot live not only on glaciers or under glaciers but also in any areas with deeply freezing soil. The latest available dates for records of some mammal species in the British Isles are as follows: terminal Pleistocene for the woolly mammoth (12 $320 \pm 120$ years before present) and saiga (12 $100 \pm 140)$; Holocene for the moose (11 $190 \pm 100)$, northern mole vole Ellobius talpinus (10 $370 \pm 90)$, currently absent west of southern Ukraine, steppe pika Ochotona pusilla (10 $180 \pm 90)$, currently absent west of the Volga, arctic lemming Dicrostonyx torquatus $(10000 \pm 80)$, which "retreated" eastward beyond the White Sea, lynx $(8875 \pm 70)$, giant deer $(6816 \pm 35)$, brown bear $(6410 \pm 110)$, wild pig $(4730 \pm 80)$, aurochs $(4040 \pm 60)$, bison (3870 \pm 60$)$, horse (3050 \pm \pm 80 , later dates are also available), and beaver $(2900 \pm 60)$. The following species that accompanied the woolly mammoth during the coldest period of the Pleistocene are currently extant in the British Isles: the European mole, red fox, and red deer, and reindeer, which is currently rather rare and confined to Scotland [50]. It is also worth noting that not only the British Isles but also Scandinavia (including extreme southern areas) are inhabited by some amphibians and reptiles (five amphibian and six reptilian species and nine amphibian and six reptilian species, respectively [51]. This fauna could have dispersed into the two regions only "by dry land", i.e., during a period of sufficiently pronounced regression, which either coincided with the coldest period of Pleistocene or took place much earlier, but according to the latter scenario the presence of those species should not (could not) have been disrupted by glaciation. In any case, either of the two scenarios contradicts the glacier hypothesis, also contradicted by the presence of endemic plants distributed northward to Greenland.

Finally, let us discuss yet another peculiar feature of the vivid and rapid faunistic transformations that took place in the Nearctic. It would have seemed natural if the first extinctions of the many taxa that disappeared in the Nearctic around the Pleistocene-Holocene boundary were those of edentates (the largest armadillos and terrestrial sloths), splendidly protected from any predators but defenseless in the face of primitive hunters, like giant tortoises. In reality, however, the first extinctions were those of the larger carnivores specialized at preying either on the largest herbivores typical of pasture ecosystems (the saber-toothed Homotherium and Smilodon and the lion) or on relatively small but the most abundant herbivores typical of pasture ecosystems (the cheetah). It would have seemed that the relatively low abundance of the larger carnivores, similar to that of edentates (especially compared to those of the most abundant ungulate species and extremely valuable proboscideans, also hunted at a limited scale), and the extremely high danger of hunting them could have safely protected them from early extinction. However, these factors failed to protect them. So, why did they prove the most vulnerable and why did they become extinct in the Nearctic millennia earlier than some herbivores, including the woolly mammoth and mastodon, while bison remained abundant until the 19th century, and reindeer remains rather abundant over large areas of North America to this day? The larger carnivores "strategically" lose to the larger herbivores not only because of their narrower specialization and position at the very top of the food pyramid. It is no less important that their offspring, in contrast to those of ungulates, proboscideans, and edentates, is born quite helpless. It takes rather long for the young of these carnivores to reach even partial independence (the ability to accompany their mother or pride). By contrast, a reindeer calf can successfully outrun a single wolf as early as several hours after birth [52]. Therefore, the very capacity of the larger carnivores to reproduce normally became more and more restricted as a result of various activities of primitive hunters, even if they did not aim at directly exterminating their main competitors.

\section{Conclusions}

It can be concluded with some certainty from the facts given here and in my earlier study [3] that 
the hypothetical giant surface glaciations covering areas of millions of square kilometers actually never happened, and climates similar to that of the Antarctic, required for the emergence of such glaciations and their existence over millennia, did not exist in the Northern Hemisphere. This statement by no means denies any changes of the climate whatsoever, but implies that such changes took place at much more moderate and "reasonable" scales. The causes of the emergence and establishment of the glacier hypothesis were splendidly outlined by Zagorskaya [53], who argued that the lithological image of the moraine has long been lost, and lost for good. As for the catastrophic climatic perturbations that caused worldwide mass extinctions of many groups, they were most probably associated with the "landing" of giant asteroids at the Permian-Triassic boundary and at the Cretaceous-Paleogene boundary [54]. But this problem should be discussed in more detail separately, in another study.

The clear and quite considerable differences in the timing, direction, and scale of changes in the composition of mammal faunas, especially those of large mammals of pasture ecosystems, within the Palearctic and Nearctic (as well as outside them in the vast majority of cases) were initially determined by profound differences in the timing, duration, and some other peculiar features of the colonization of these areas by humans. However, the extinction of particular taxa should not be reduced to mere consequence of direct extermination. The scenario was much more complex. Ecosystems of Eurasia were first colonized by our ancestor Homo erectus earlier than 1 million years before present and therefore affected by humans for immeasurably longer than those of North America, where the events in question started to unfold in earnest only 14 to 5 thousand years before present, but where the "professional" level of the primitive hunter colonists "allied" with the domesticated wolf (dog) was from the very beginning as high or almost as high as ever. Moreover, this "economic lifestyle", initial for the pioneers of America, remained essentially unchanged in the Nearctic until the European colonization, and $\mathrm{Na}$ tive Americans remained hunter-gatherers in most of extratropical North America.

It must be taken into account that in the much larger Palearctic region humans, which colonized it since the Early Pleistocene, possessed fire for hundreds of millennia and used it for such a long time with inevitable ecological consequences.

In my previous study [3] I discussed the causes of the special vulnerability of woolly mammoths, as well as modern elephants, and their first-rate value for primitive hunters. The considerable de- crease of their abundance, followed by decrease in the abundance of other principal edificator species of pasture ecosystems, inevitably led to the following consequences of utmost importance. (1) Degradation of this type of ecosystems over larger and larger areas increased, especially in regions with the most humid climates. As a result, the giant pasture ecosystem zone of the Palearctic is in effect "cut" through these regions by the more and more strongly developed forest zone into two parts, so that at present the zone of forest-tundra to polar deserts is distributed north of the forest zone and a zone of forest-steppes to deserts is distributed south of the forest zone. This resulted in extinction in some taxa and cardinal range changes in others. (2) The economic structure of primitive hunters underwent a growing crisis: this crisis quite clearly peaked in the Palearctic as early as the Mesolithic, at the Late Pleistocene - Holocene boundary, whereas in most of the Nearctic clear manifestations of this crisis did not become evident until the European colonization.

The geographical differences between the main continents of the Old World and New World most probably quite strongly determined the subsequent (post-Mesolithic) course of events within the Palearctic and Nearctic. In the Palearctic, the extremely long zone of inevitable contacts between foci of the "Neolithic revolution" and more northern areas determined the very broad and rapid spread of crop farming and especially animal husbandry, up to the two essentially different reindeer husbandry lifestyles [55]. It should be noted that in some areas of the Palearctic the primitive hunter-fisher-gatherer lifestyle did not disappear [49]. The less pronounced Neolithic foci (comparatively tiny) of South and Central America, additionally rather isolated, had almost no principal effects on the fate of the Native American population over most of the Nearctic until the European colonization.

The domestication of the horse and invention (originally by Scythians) of the saddle - still unknown, for instance, to Alexander the Great - were of colossal importance in many areas of the Palearctic and subsequently in most other areas. The later fate of mammal faunas and the whole biosphere was more and more determined by the technological development of the human civilization, although the term "civilization" sometimes appears inappropriate even in the 21 st century.

It can be concluded from all above-said, including my earlier study, that the known changes in the compositions of mammal faunas in the Palearctic and Nearctic, which followed essentially different "scenarios" during the terminal Cenozoic, including the Holocene, and the considerable changes of ranges in the extant species and genera (many of 
which have not been discussed above) cannot be linked to climate changes, which were simultaneous in extratropical latitudes of the Northern Hemisphere. Human activity was the initial cause of these changes, gradually resulting in decreasing abundance (population density) and eventually extinction of the main edificator species of pasture ecosystems, inevitably causing the growing (especially in the Palearctic) degradation and profound transformation of pasture ecosystems, and thus causing another series of inevitable consequences, which should be discussed in a separate broad review. It was the growing degradation of pasture ecosystems and their disappearance over huge are- as that were later conductive not only to the extinction of some taxa and principal changes in the ranges of many others but also to profound transformation of vegetation over colossal areas, an event that inevitably had to affect the climate.

\section{Acknowledgments}

I am deeply grateful to A. K. Agadzhanyan, N. N. Kalandadze, M. V. Kalyakin, T. V. Kuznetsova, A. P. Rasnitsyn, and O. V. Smirnova, who kindly provided me with some extremely valuable publications and information.

\section{References}

1. Клиге, Р. К. История гидросферы / Р. К. Клиге, И. Д. Данилов, В. Н. Конищев. - М. : Научный мир, 1998. $368 \mathrm{c.}$

2. Калякин, В. Н. Структура орнитофауны Арктики / В. Н. Калякин // Материалы VII Всероссийской зоогеографической конференции. - М. : Наука, 1979. - С. 27-30.

3. Калякин, В. Н. О причинах и последствиях распада мамонтовых фаун / В. Н. Калякин // Успехи современной биологии. -2014 . - Т. 134, № 1. - С. 81-96.

4. Смирнова, О. В. Современная зональность Восточной Европы как результат преобразования позднеплейстоценового комплекса ключевых видов / О. В. Смирнова, В. Н. Калякин, С. А. Турубанова, М. В. Бобровский // Мамонт и его окружение: 200 лет изучения. - М. : ГЕОС, 2001. - С. 200-208.

5. Смирнова, О.В.Генезис восточноевропейской тайги в голоцене / О. В. Смирнова, В. Н. Калякин, С. А. Турубанова, Е. Ю. Бакун // Закономерности вековой динамики биогеоценозов. ХХІ Чтения памяти В. Н. Сукачёва. - М. : Товарищество научных изданий КМК, 2006. - С. 18-65.

6. McKenna, M. C. Classification of Mammals Above the Species Level / M. C. McKenna, S. K. Bell. - New York : Columbia University Press, 1998. - 631 p.

7. Mammals species of the world: a taxonomic and geographic reference / ed. by D. E. Wilson, D. M. Reeder. - Baltimore : The Johns Hopkins University Press, 2005. - Vol. 1. - 743 p. ; Vol. 2. - P. 744-2142.

8. Леви, К. Г. Радиоуглеродная хронология природных и социальных феноменов Северного полушария. Т. 1 / К. Г. Леви, Н. В. Задонина, С. А. Язев. - Иркутск : Изд-во Иркут. гос. ун-та, 2009. - 715 с.

9. Леви, К. Г. Радиоуглеродная хронология природных и социальных феноменов Северного полушария. Т. 2 / К. Г. Леви, Н. В. Задонина, С. А. Язев. - Иркутск : Изд-во Иркут. гос. ун-та, 2011. - 527 с.

10. Леви, К. Г. Радиоуглеродная хронология природных и социальных феноменов Северного полушария. Т. 3 / К. Г. Леви, Н. В. Задонина, С. А. Язев. - Иркутск : Изд-во Иркут. гос. ун-та, 2011. - 847 с.

11. Гептнер, В. Г. Млекопитающие Советского Союза. Т. 2 (часть вторая) / В. Г. Гептнер, А. А. Слудский. М. : Высш. шк., 1972. - 551 с.

12. Гептнер, В. Г. Млекопитающие Советского Союза. Парнокопытные и непарнокопытные. Т. 1 / В. Г. Гептнер, А. А. Насимович, А. Г. Банников. - М. : Высш. шк., 1961. - 776 с.

13. Гептнер, В. Г. Млекопитающие Советского Союза. Т. 2 (часть первая) / В. Г. Гептнер, Н. П. Наумов, П. Б. Юргенсон [и др.]. - М. : Высш. шк., 1967. - 1004 с.

14. Громов, И. М. Млекопитающие фауны СССР. Ч. 1 / И. М. Громов, А. А. Гуреев, Г. А. Новиков [и др.]. М. ; Л. : Изд-во АН СССР, 1963. - 639 с.

15. Громов, И. М. Млекопитающие фауны СССР. Ч. 2 / И. М. Громов, А. А. Гуреев, Г. А. Новиков [и др.]. М. ; Л. : Изд-во АН СССР, 1963. - С. 640-1101.

16. Соколов, В. Е. Систематика млекопитающих. Отряды: однопроходных, сумчатых, насекомоядных, шерстокрылов, рукокрылых, приматов, неполнозубых, ящеров / В. Е. Соколов. - М. : Высш. шк., 1973. - 432 с.

17. Соколов, В. Е. Систематика млекопитающих. Отряды: зайцеобразных, грызунов / В. Е. Соколов. - М. : Высш. шк., 1977. - 494 с.

18. Соколов, В. Е. Систематика млекопитающих. Отряды: китообразных, хищных, ластоногих, трубкозубых, хоботных, даманов, сирен, парнокопытных, мозоленогих, непарнокопытных / В. Е. Соколов. - М. : Высш. шк., 1979. $-528 \mathrm{c}$.

19. Каталог млекопитающих СССР / под ред. И. М. Громова, Г. И. Барановой. - Л. : Наука, 1981. - 456 с.

20. Quaternary Extinction. A Prehistoric Revolution // ed. by P. S. Martin, R. G. Klein. - Tucson, Arizona : University Arizona Press, 1984. - 867 p.

21. Forsyth, A. Mammals of the Canadian Wild / A. Forsyth. - Camden East : Camden House, 1985. - 351 p.

22. Кэрролл, Р. Палеонтология и эволюция позвоночных. Т. 3 : пер. с англ. / Р. Кэрролл. - М. : Мир, 1993. $310 \mathrm{c}$. 
23. Memorie della Società Italiana di Scienze Naturali e del Museo Civico di Storia Naturale di Milano. XXVI. Fasc. 2. L'arte e l'ambiente del Sahara preistorico: dati e interpretazioni. - Milan, 1993. - 556 p.

24. Kingdon, J. The Kingdon Field Guide to African Mammals / J. Kingdon. - London : Natural World Academic Press, 1997. -465 p.

25. Рич, П. В. Каменная книга. Летопись доисторической жизни : пер. с англ. / П. В. Рич, Т. Х. Рич, М. А. Фентон. - М. : Наука, 1997. - 623 с.

26. Жегалло, В. И. Судьба мегафауны Голарктики в позднем антропогене / В. И. Жегалло, Н. Н. Каландадзе, Т. В. Кузнецова, А. С. Раутиан // Мамонт и его окружение: 200 лет изучения. - М. : ГЕОС, 2001. C. 287-306.

27. Мамонт и его окружение: 200 лет изучения / отв. ред. А. Ю. Розанов. - М. : ГЕОС, 2001. - 361 с.

28. Павлинов, И. Я. Систематика современных млекопитающих / И. Я. Павлинов. - М. : Изд-во Моск. ун-та, 2003. - $297 \mathrm{c}$.

29. Маркова, А. К. Эволюция экосистем Европы при переходе от плейстоцена к голоцену (24-8 тыс. л. н.) / А. К. Маркова, Т. ван Кольфсхотен. - М. : Товарищество научных изданий КМК, 2008. - 556 с.

30. Лот, А. В поисках фресок Тассилин-Аджера / А. Лот. - Л. : Искусство, 1973. - 111 с.

31. Лот, А. К другим Тассили. Новые открытия в Сахаре / А. Лот. - Л. : Искусство, 1984. - 215 с.

32. Camps, G. Hérodote et l'art rupestre. Recherches sur la Faune des temps néolitiques et protohistoriques de l'Afrique du Nord / G. Camps // Memorie della Società Italiana di Scienze Naturali e del Museo Civico di Storia Naturale di Milano. - Milano, 1993. - Fasc. 2. - P. 125-134.

33. Gautier, A. Mammifères holocènes du Sahara d'après l'art rupestre et l'archéozoologie / A. Gautier // Memorie della Società Italiana di Scienze Naturali e del Museo Civico di Storia Naturale di Milano, 1993. - Fasc. 2. P. 261-267.

34. Симпсон, Дж. Великолепная изоляция : пер. с англ. / Дж. Симпсон. - М. : Мир, 1983. - 256 с.

35. Каландадзе, Н. Н. Система млекопитающих и историческая зоогеография / Н. Н. Каландадзе, А. С. Раутиан // Филогенетика млекопитающих. - М. : Изд-во Моск. ун-та, 1992. - С. 44-152.

36. Kuznetzova, T. V. New data on the "Mammoth" fauna of the Laptev Shelf Land (East Siberian Arctic) / T. V. Kuznetzova, L. D. Sulerzhitsky, C. Siegert // The World of Elephants. - Rome, 2001. - P. 289-292.

37. Косинцев, П. А. Комплексы млекопитающих раннего голоцена (пребореал-бореал). Вымирания млекопитающих на территории Европы в конце плейстоцена - голоцене / П. А. Косинцев // Эволюция экосистем Европы при переходе от плейстоцена к голоцену (24-8 тыс. л. н.) / отв. ред. А. К. Маркова, Т. ван Колфсхотен. - М. : Товарищество научных изданий КМК, 2008. - С. 233-270.

38. Masseti, M. Did endemic dwarf elephants survive on Mediterranean islands up to protohistorical times? / M. Masseti // The World of Elephants. - Rome, 2001. - P. 402-406.

39. Saegusa, H. Comparison of stegodon and elephantid abundances in the date Pleistocene of southern China/ H. Saegusa // The World of Elephants. - Rome, 2001. - P. 345-349.

40. Любин, В. П. Ното erectus - первооткрыватель Евразии / В. П. Любин // Природа. - 1997. - № 11. C. $3-12$

41. Иванова, И. К. О геологическом возрасте ископаемых гоминид в свете данных абсолютного летоисчисления / И. К. Иванова // Ископаемые гоминиды и происхождение человека. - М. : Наука, 1966. - С. 5-42.

42. Уэллс, С. Генетическая одиссея человека : пер с англ. / С. Уэллс. - М. : Альпина нон-фикшн, 2013. - 276 с.

43. Марков, А. Эволюция человека. І. Обезьяны, кости и гены / А. Марков. - М. : Астрель, 2012. - 464 с.

44. Береговая, Н. А. Палеолитические местонахождения СССР / Н. А. Береговая. - М. ; Л. : Изд-во АНСССР, 1960. - $210 \mathrm{c}$

45. Береговая, Н. А. Палеолитические местонахождения СССР / Н. А. Береговая. - Л. : Наука, $1984 .-171$ с.

46. Ovodov, N. D. A 33000-year-old incipient dog from the Altai mountains of Siberia: evidence of the earliest domestication disrupted by the last glacial maximum / N. D. Ovodov, S. J. Crockford, Y. V. Kuzmin [et al.] // PloS One. - 2011. - Vol. 6, no. 7. - P. 1-7.

47. Четвертичный период в США. Т. II : пер. с англ. / под ред. Г. Райта и Д. Фрея. - М. : Мир, 1969. - 345 с.

48. Шнирельман, В. А. Древние культуры и цивилизации / В. А. Шнирельман // Коренное население Северной Америки в современном мире. - М. : Наука, 1990. - С. 28-44.

49. Шнирельман, В. А. Позднепервобытная община земледельцев-скотоводов и высших охотников, рыболовов и собирателей / В. А. Шнирельман // История первобытного общества. Эпоха первобытной родовой общины. - М. : Наука, 1986. - С. 236-426.

50. Burton, J. A. Field Guide to the Mammals of Britain \& Europe / J. A. Burton. - London : Kingfisher Books, 1991. - $191 \mathrm{p}$.

51. Engelmann, W. E. Lurche und Kriechtiere Europas / W. E. Engelmann, J. Fritzsche, R. Gunter, F. J. Obst. Leipzig, Radedeul : Neumann Verlag, 1985. - 420 p.

52. Моуэт, Ф. Не кричи, волки! : пер. с англ. / Ф. Моуэт. - М. : Мир, 1968. - 149 с.

53. Загорская, Н. Г. Морские неоген-четвертичные отложения нижнего течения реки Енисей / Н. Г. Загорская, 3. И. Яшина, В. Я. Слободин, Ф. М. Левина, А. М. Белевич // Труды Института геологии Арктики. - М. : Недра, 1965. - Т. 144. - 92 с.

54. Jankc, P. R. Correlated History of Earth / P. R. Jankc. - 2007.

55. Помишин, С. Б. Происхождение оленеводства и доместикация северного оленя / С. Б. Помишин. - М. : Наука, 1990. - 141 с. 


\section{References}

1. Klige R. K., Danilov I. D., Konishchev V. N. Istoriya gidrosfery [History of the Hydrosphere]. Moscow: Nauchnyy mir, 1998, 368 p.

2. Kalyakin V. N. Materialy VII Vserossiyskoy zoogeograficheskoy konferentsii [Proceedings of VII Russian Conference of Zoology and Geography]. Moscow: Nauka, 1979, pp. 27-30.

3. Kalyakin V. N. Uspekhi sovremennoy biologii [Current Advances of Biology]. 2014, vol. 134, no. 1, pp. 81-96.

4. Smirnova O. V., Kalyakin V. N., Turubanova S. A., Bobrovskiy M. V. Mamont i ego okruzhenie: 200 let izucheniya [Mammoth and Its Environment: 200 Years of Study]. Moscow: GEOS, 2001, pp. 200-208.

5. Smirnova O. V., Kalyakin V. N., Turubanova S. A., Bakun E. Yu. Zakonomernosti vekovoy dinamiki biogeotsenozov. XXI Chteniya pamyati V. N. Sukacheva [Regularities of Age Dynamics of Biogecenoces. XXI Readings dedicated to V.N. Sukachev]. Moscow: Tovarishchestvo nauchnykh izdaniy KMK, 2006, pp. 18-65.

6. McKenna M. C., Bell S. K. Classification of Mammals Above the Species Level. New York: Columbia University Press, 1998, $631 \mathrm{p}$

7. Mammals species of the world: a taxonomic and geographic reference. Ed. by D. E. Wilson, D. M. Reeder. Baltimore: The Johns Hopkins University Press, 2005, vol. 1, 743 p.; vol. 2, pp. 744-2142.

8. Levi K. G., Zadonina N. V., Yazev S. A. Radiouglerodnaya khronologiya prirodnykh i sotsial'nykh fenomenov Severnogo polushariya. T. 1 [Radiocarbon Chronology of Natural and Social Phenomena in Northern Hemisphere]. Irkutsk: Izd-vo Irkut. gos. un-ta, 2009, 715 p.

9. Levi K. G., Zadonina N. V., Yazev S. A. Radiouglerodnaya khronologiya prirodnykh i sotsial'nykh fenomenov Severnogo polushariya. T. 2 [Radiocarbon Chronology of Natural and Social Phenomena of Northern Hemisphere]. Irkutsk: Izd-vo Irkut. gos. un-ta, 2011, 527 p.

10. Levi K. G., Zadonina N. V., Yazev S. A. Radiouglerodnaya khronologiya prirodnykh i sotsial'nykh fenomenov Severnogo polushariya. T. 3 [Radiocarbon Crhonology of Natural and Social Phenomena in Northern Hemisphere]. Irkutsk: Izd-vo Irkut. gos. un-ta, 2011, 847 p.

11. Geptner V. G., Sludskiy A. A. Mlekopitayushchie Sovetskogo Soyuza. T. 2 (chast' vtoraya) [Mammals of the USSR. Vol.2]. Moscow: Vyssh. shk., 1972, 551 p.

12. Geptner V. G., Nasimovich A. A., Bannikov A. G. Mlekopitayushchie Sovetskogo Soyuza. Parnokopytnye i neparnokopytnye. T. 1 [Mammals of the USSR. Vol.1]. Moscow: Vyssh. shk., 1961, 776 p.

13. Geptner V. G., Naumov N. P., Yurgenson P. B. et al. Mlekopitayushchie Sovetskogo Soyuza. T. 2 (chast' pervaya) [Mammals of the USSR. Vol.2]. Moscow: Vyssh. shk., 1967, 1004 p.

14. Gromov I. M., Gureev A. A., Novikov G. A. et al. Mlekopitayushchie fauny SSSR. Ch. 1 [Mammalian Fauna of the USSR. Volume 1]. Moscow; Leningrad: Izd-vo AN SSSR, 1963, 639 p.

15. Gromov I. M., Gureev A. A., Novikov G. A. et al. Mlekopitayushchie fauny SSSR. Ch. 2 [Mammalian Fauna of the USSR. Volume 2]. Moscow; Leningrad: Izd-vo AN SSSR, 1963, pp. 640-1101.

16. Sokolov V. E. Sistematika mlekopitayushchikh. Otryady: odnoprokhodnykh, sumchatykh, nasekomoyadnykh, sherstokrylov, rukokrylykh, primatov, nepolnozubykh, yashcherov [Mamal Taxonomy. Orders: Monotremata, Marsupialia, Insectivora, Dermoptera, Chiroptera, Primates, Pilosa, Pholidota]. Moscow: Vyssh. shk., 1973, 432 p.

17. Sokolov V. E. Sistematika mlekopitayushchikh. Otryady: zaytseobraznykh, gryzunov [Mammal Taxonomy: Lagomorpha, Rodentia]. Moscow: Vyssh. shk., 1977, 494 p.

18. Sokolov V. E. Sistematika mlekopitayushchikh. Otryady: kitoobraznykh, khishchnykh, lastonogikh, trubkozubykh, khobotnykh, damanov, siren, parnokopytnykh, mozolenogikh, neparnokopytnykh [Mammal Taxonomy: Cetacea, Carnivora, Pinnipeds, Tubulidentata, Proboscidea, Hyracoidea, Sirenia, Artiodactyla, Tylopoda, Perissodactyla]. Moscow: Vyssh. shk., 1979, 528 p.

19. Katalog mlekopitayushchikh SSSR [Catalogue of Mammals of the USSR]. Ed. by I. M. Gromov, G. I. Baranova. Leningrad: Nauka, 1981, $456 \mathrm{p}$.

20. Quaternary Extinction. A Prehistoric Revolution. Ed. by P. S. Martin, R. G. Klein. Tucson, Arizona: University Arizona Press, 1984, 867 p.

21. Forsyth A. Mammals of the Canadian Wild. Camden East: Camden House, 1985, 351 p.

22. Carrol R. Paleontologiya i evolyutsiya pozvonochnykh. T. 3: per. s angl. [Vertebrate Paleontology and Evolution. Vol. 3. Transl. from Eng.]. Moscow: Mir, 1993, 310 p.

23. Memorie della Società Italiana di Scienze Naturali e del Museo Civico di Storia Naturale di Milano. XXVI. Fasc. 2. L'arte e l'ambiente del Sahara preistorico: dati e interpretazioni [Proceedings of the Italian Society of Natural Sciences at the City Museum of Natural History in Milan. XXVI Vol. 2. Art and Environment of Prehistoric Sahara: Data and Interpretations]. Milan, 1993, 556 p.

24. Kingdon J. The Kingdon Field Guide to African Mammals. London: Natural World Academic Press, 1997,465 p.

25. Rich P. V., Rich T. H., Fenton M. A. Kamennaya kniga. Letopis' doistoricheskoy zhizni: per. s angl. [The Fossil Book. A Record of Prehistoric Life. Transl. from Eng.]. Moscow: Nauka, 1997, 623 p.

26. Zhegallo V. I., Kalandadze N. N., Kuznetsova T. V., Rautian A. S. Mamont i ego okruzhenie: 200 let izucheniya [Mammoth and Its Environment: 200 Years of Study]. Moscow: GEOS, 2001, pp. 287-306.

27. Mamont i ego okruzhenie: 200 let izucheniya [Mammoth and Its Environment: 200 Years of Study]. Ed. A. Yu. Rozanov. Moscow: GEOS, 2001, 361 p. 
28. Pavlinov I. Ya. Sistematika sovremennykh mlekopitayushchikh [Extant Mammals Taxonomy]. Moscow: Izd-vo Mosk. un-ta, 2003, 297 p.

29. Markova A. K., T. van Kol'fskhoten Evolyutsiya ekosistem Evropy pri perekhode ot pleystotsena $k$ golotsenu (24-8 tys. l. n.) [Evolution of the Ecosystems in Europe during Transition from the Pleistocene to the Holocene (24-8 millennia before now)]. Moscow: Tovarishchestvo nauchnykh izdaniy KMK, 2008, 556 p.

30. Lot A. V poiskakh fresok Tassilin-Adzhera [In Search of Tassili n'Ajjer Art]. Leningrad: Iskusstvo, 1973,111 p.

31. Lot A. K drugim Tassili. Novye otkrytiya v Sakhare [New Tassili. New Discoveries in Sahara]. Leningrad: Iskusstvo, 1984, $215 \mathrm{p}$.

32. Camps G. Memorie della Società Italiana di Scienze Naturali e del Museo Civico di Storia Naturale di Milano [Proceedings of the Italian Society of Natural Sciences at the City Museum of Natural History in Milan]. Milano, 1993, iss. 2, pp. 125-134.

33. Gautier A. Memorie della Società Italiana di Scienze Naturali e del Museo Civico di Storia Naturale di Milano [Proceedings of the Italian Society of Natural Sciences at the City Museum of Natural History in Milan]. Milano, 1993, iss. 2, pp. 261-267.

34. Simpson Dzh. Velikolepnaya izolyatsiya: per. s angl. [Splendid Isolation. The Curious History of South American Mammals. Transl. from Eng.]. Moscow: Mir, 1983, 256 p.

35. Kalandadze N. N., Rautian A. S. Filogenetika mlekopitayushchikh [Phylogenesis of Mammals]. Moscow: Izd-vo Mosk. un-ta, 1992, pp. 44-152.

36. Kuznetzova T. V., Sulerzhitsky L. D., Siegert C. The World of Elephants. Rome, 2001, pp. $289-292$.

37. Kosintsev P. A. Evolyutsiya ekosistem Evropy pri perekhode ot pleystotsena $k$ golotsenu (24-8 tys. l. n.) [Evolution of the Ecosystems in Europe during Transition from the Pleistocene to the Holocene (24-8 millennia before now)]. Moscow: Tovarishchestvo nauchnykh izdaniy KMK, 2008, pp. 233-270.

38. Masseti M. The World of Elephants. Rome, 2001, pp. 402-406.

39. Saegusa H. The World of Elephants. Rome, 2001, pp. 345-349.

40. Lyubin V. P. Priroda [Nature]. 1997, no. 11, pp. 3-12.

41. Ivanova I. K. Iskopaemye gominidy i proiskhozhdenie cheloveka [Fossil Hominids and the Origin of Humans]. Moscow: Nauka, 1966, pp. 5-42.

42. Wells S. Geneticheskaya odisseya cheloveka: per s angl. [The Journey of Man: A Genetic Odyssey. Transl. from Eng.]. Moscow: Al'pina non-fikshn, 2013, 276 p.

43. Markov A. Evolyutsiya cheloveka. I. Obez'yany, kosti i geny [Human Evolution]. Moscow: Astrel', 2012,464 p.

44. Beregovaya N. A. Paleoliticheskie mestonakhozhdeniya SSSR [Paleolithic Sites in the USSR]. Moscow; Leningrad: Izd-vo ANSSSR, 1960, 210 p.

45. Beregovaya N. A. Paleoliticheskie mestonakhozhdeniya SSSR [Paleolithic Sites in the USSR]. Leningrad: Nauka, 1984, $171 \mathrm{p}$.

46. Ovodov N. D., Crockford S. J., Kuzmin Y. V. et al. PloS One. 2011, vol. 6, no. 7, pp. 1-7.

47. Chetvertichnyy period v SShA. T. II: per. s angl. [The Quaternary Period in the USA. Vol. 2. Transl. from Eng.]. Ed. G. Rayt and D. Frey. Moscow: Mir, 1969, 345 p.

48. Shnirel'man V. A. Korennoe naselenie Severnoy Ameriki v sovremennom mire [Androgeneous Population of North America in the Current World]. Moscow: Nauka, 1990, pp. 28-44.

49. Shnirel'man V. A. Istoriya pervobytnogo obshchestva. Epokha pervobytnoy rodovoy obshchiny [History of Primitive Society. Epoch of Primitive Tribal Community]. Moscow: Nauka, 1986, pp. 236-426.

50. Burton J. A. Field Guide to the Mammals of Britain \& Europe. London: Kingfisher Books, 1991,191 p.

51. Engelmann W. E., Fritzsche J., Gunter R., Obst F. J. Lurche und Kriechtiere Europas [Europe's Amphibians and Reptiles]. Leipzig, Radedeul: Neumann Verlag, 1985, 420 p.

52. Mowat F. Ne krichi, volki!: per. s angl. [Never Cry Wolf: transl. from Eng.]. Moscow: Mir, 1968,149 p.

53. Zagorskaya N. G., Yashina Z. I., Slobodin V. Ya., Levina F. M., Belevich A. M. Trudy Instituta geologii Arktiki [Proceedings of the Institute of Arctic Geology]. Moscow: Nedra, 1965, vol. 144, 92 p.

54. Jankc P. R. Correlated History of Earth. 2007.

55. Pomishin S. B. Proiskhozhdenie olenevodstva i domestikatsiya severnogo olenya [Origins of Reindeer Husbandry and Domestication]. Moscow: Nauka, 1990, 141 p. 